\title{
Design and Evaluation of a Complex Phytoceutical Formulation for Circulatory Diseases
}

\author{
Olalde J, Antoshechkin A, del Castillo O, Guzmán R and Améndola, F \\ Centro Medico Docente Adaptogenos \\ Venezuela
}

\section{Introduction}

Although herbal/natural remedies have been, and are still being used, in the treatment of chronic degenerative diseases, little is known about basic principles -or theory- to combine these components and attain synergistic, gene modulating, as well as clinical health improving effects. This chapter is divided into six sections. Section 2 reviews the background which gives origin and establishes the Systemic Theory and Systemic Medicine. The section also provides the general precepts to structure Circulat -a complex herbal formulation- for the treatment of circulatory chronic degenerative diseases. Section 3 is an outline of an investigation into the aforementioned formulation's role and capability to modulate various gene expression levels -in cultured human fibroblasts- including those associated with diabetes. On the other hand, Section 4 presents a review of Circulat's clinical properties through a Diabetic Foot management Study. An abbreviated limited Phase 2 GSPECT evaluated Chronic Ischemic Disease -another circulatory chronic disease- study is presented in Section 5. Finally, Section 6 provides some conclusions concerning the use of a complex herbal formulation as well as some reflections on the future design of such compositions.

\section{The origin of Systemic theory and Systemic medicine: Relevance to complementary and alternative medicine}

Past and Present Phytomedicine and natural practitioners: Tomorrow's Systemics? Recent past -and even present- successful phytomedicine practitioners and naturalists share a long and honorable tradition of knowledge and pride in the cure of illnesses, which goes back to written history and beyond. These qualities have been substantiated by the successes of the Chinese (Chen et al., 2004; Wago \& Deng, 2004), Kampo (Teresawa, 2004; Yamada, 2004), Ayurvedic (Naik et al., 2003), Chumash (Adams and Garcia, 2005) or Mayan (Peña, 2002) traditional medicines among many others. These traditional medicines 'demonstrated that every culture is capable of understanding and "inventing" the meaning of disease and its cure, even when it is different from our modern medical views' (Peña, 2002). The variability and extent of cultures to provide answers -or traditional medicines- to pathologies are embedded in the curiosity and observational 
capabilities of the human race. There are also collective factors such as 'a background of extensive family in traditional medicine' (Vandenbroek et al., 2004) which play an important role in the communication and survival of medicinal plant knowledge among ethnic groups. A potential issue, though, is the possible curtailment of the wisdom -and therapies- of traditional medicines within geographical and ethnic boundaries. In any case, the amount of plants, potential formulations or properties are a massive concern for any given individual caregiver or group to understand, store and transmit. Some exceptional individuals seem to have come by this ability. One of these gifted health care practitioners was Maurice Messegue, whom Mistinguet and Konrad Adenaur -among his famous patients- swore that only he could treat their illnesses. More recently, both, Dr. Rusudan Lomidze, using the Georgian Kohlkian traditional medicine, and Lonrig Dangar, a Tibetan physician who applied the rich Tibetan traditional medicine have also obtained significant success. These gifted individuals have shown that traditional medicine is a successful medicine. But a question still hangs in the air. Might a theory be devised by which regular practitioners, health care specialists devoid of the naturalists' extensive background, formulate natural organic therapeutic protocols? Furthermore, is it possible to set up a system -or periodic table- where plants and other natural remedies could, according to superior therapeutic properties, be arranged to produce specific formulae that provide well-being for a given pathology? The treatment of circulatory pathologies with substances which act only on function and structure might be an incomplete approach. Whether the investigations in circulatory chronic disease studies -and their results- can be generalized in confirmation of a systemic approach is something that should be pursued as this may pave the way for a new integral vision of therapeutics in general and/or in circulatory chronic diseases such as Diabetes in particular.

\subsection{Prior developments of a natural therapeutic protocol: Systemic Theory}

Aggressors or stressors were identified by Professor Hans Selye, and described and classified in over 1500 articles and 32 books. He formulated the General Adaptation Syndrome (Selye, 1976), which classified effects on animals and humans affected by threats (exhaustion, disease, fear, extreme cold ...) as: alarm (body's recognition of danger and its preparation to deal with threats); resistance (or adaptation, in which the body adapts to resist stress); and exhaustion (condition in which the body's energy supply is depleted). The next step was taken by Soviet scientists led by Lazarev and Brekhman, who investigated properties of substances, with the ability to increase adaptability and resistance to stress. They named these 'adaptogens'. By 1960 more than 1000 studies had been published by Soviet scientists concerning the use of adaptogens. In 1962, Eleutherococcus senticosus, Rhaponticum carthamoides and Rhodiola rosea, all adaptogens, were included in the Soviet Union's Pharmacopoeia. Since then many other plants and sources have been found to have similar properties (Brekman and Ivanov, 1969; Khasina et al., 1983; Bhattacharya and Muruganandam, 2003; Dhuley, 2000) and increasing resistance to stressors as depicted by Selye, enhancing energy, and regulating immune, neuroendocrine and cellular function. Although the adaptogen definition in science is questioned by some researchers, most concur on their health enhancing properties (Davydov and Krikorian, 2000). Figure 1

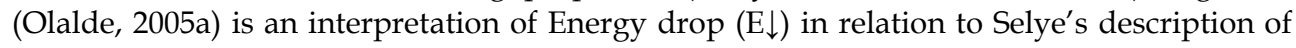
biochemical collapse $(\mathrm{I} \downarrow)$ and organic dysfunction $(\mathrm{O} \downarrow)$. This paved the way to the $\mathrm{E}$, I and $\mathrm{O}$ triangle. 


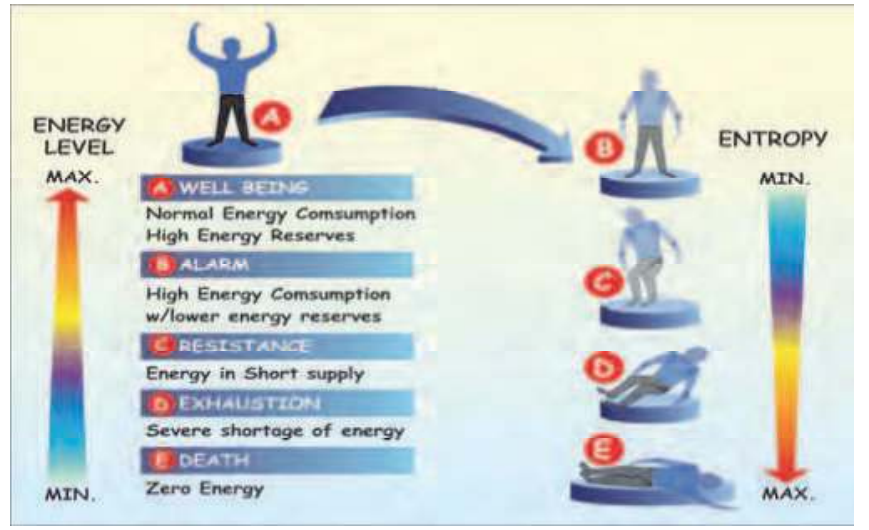

Fig. 1. Functional energy reserve ladder. Energy drop affects the human organism, going from a state of well being with high Energy reserves and low entropy - low disorderthrough various stages and finally to that of death, or state of zero energy and maximun disorder

\subsubsection{Life and negentropy: Rationalization for the use of phytomedicines}

The second law of thermodynamics states that a system logically tends to go from a state of higher energy and order to one of lower energy and disorder. This is more so in living systems where internal entropy tends to increase in its journey through life, going from health, energy and physiological order towards sickness, asthenia (the loss or lack of bodily strength; weakness) and physiological disorder. Illness, however, can be countered based on quantum physicist's Erwin Schrödinger's notion that the general change of entropy in an open system, such as a living (biological) system, consists of (i) internal entropy variations and (ii) entropy exchange of the system with the environment; i.e. $\triangle S=\Delta S$ internal $+\triangle S$ exchange. Internal entropy in a biological organism, by definition, tends to be greater than zero due to inner irreversible processes. Therefore, the increase in entropy of an open biological system, and thus illness, may be reduced (von Stockar and Liu, 1999) by providing negative entropy -or negentropy-from the environment. This is pivotal as nature provides a source of negative entropy. '... The decrease of entropy in living systems is provided by free energy, released when nutrients consumed from the outside dissociate, i.e. at the expense of the sun's energy. Thus, the flow of negative entropy is essential to compensate for inner destructive processes as well as for the decrease of available free energy dissipated by spontaneous metabolic reactions. This last, is the key point, circulation and transformation of free energy, which drives the functions of living systems ...' (Korotkov et al., 2004).

\section{$2.2 \uparrow$ Health $\leftrightarrow$ entropy $\downarrow$}

How does life defy entropy? In physics, entropy is defined as the measure of disorder in a system. Disorder, in turn, can be mathematically expressed by the probability of random occurrence. All pathologies, by definition, result from a higher than normal organic entropy; thus, to induce health, entropy must first be reduced; this is bi-conditional. Contemporary thermodynamics defines entropy (or chaos) in an intelligent system as a deficiency in energy 
and/or information. Therefore, entropy is inversely related to information and energy availability. According to Shannon -father of the Information Theory- and Weaver 'information is always a measure of the decrease of uncertainty at a receiver or molecular machine' (Shanon and Weaver, 1999). Thus was born the concept of informational entropy, which they concluded was equivalent to a shortage of information content in a message. About the same time, Weiner (Weiner, 1954) established the possibility of interpreting information carried by a message as '... essentially the negative entropy, and the negative logarithm of its probability' since 'the relationship between information (J) and thermodynamic entropy $(S)$ is constant $(S+J=$ const)' (Korotkov, 1988). Thus, the work of such eminent minds as: Boltzmann (Lindley, 2001), Gibbs (Deltete, 1995), Szilard (Leff \& Rex, 1990), Von Neumann (Heims et al., 1980), Schrödinger (1992), Prigogine (1984), Shannon and Weaver (1999) and Weiner (Heims et al., 1980; Weiner, 1954), brought about the dawn of new emergent fields, including: informational thermodynamics, information theory, biological information theory and cybernetics all dealing with energy, information and entropy in mechanical and living systems. A basic common premise in the new thinking proposes that information and energy had an inverse, i.e. opposite, correlation with entropy. In other words, evidence suggests that no suitable organization can be attained in living systems that possess reduced levels of information or energy. Disease, therefore, may be defined as a state of disorganization, i.e. higher organic entropy, corresponding with a low energo-informational status of the system. In consequence, if a reduction in illness is to be achieved, entropy must be reduced. A comprehensive way of accomplishing this, is administering negative entropy, or order, through matter which stimulates the production of energy and provides survival information to the immune, neuroendorine and cellular systems. To recap, the tendency to reach order depends on the energy and information available within the system, which determines the possible level of stable organization possible. The quantity of true information (conceptual data, not noise) transferred to the system's modulating intelligence allows for chaos and/or confusion management and, enhances the system's ability to attain a higher organization level. Moreover by definition, only an intelligent system can process information and energy to reduce entropy. This unequivocal fact demonstrates the existence of a regulating biological intelligence within the human body. Intelligence is the way in which life affronts entropy.

\subsubsection{The $E$, I and $O$ health triangle}

All living systems are functional units that seek maximum survival. The cell is the simplest form of a living system that functions as a basic building block of the living universe, just as an atom does in matter. Conversely, a virus is the simplest living unit, which in some situations acts as destroyer of living systems. I (or Intelligence) is the backbone of every living system in equilibrium. I controls, regulates, adapts and develops the living system. Chaos occurs in its absence. The proof of this is that no living system can exist without intelligence. The intelligence of the system, I, creates and utilizes E (or Energy) with the primary role of achieving $\mathbf{O}$ (Organization) and evolving into a higher system (Owens and Van de Castle, 2004). I also creates/builds $\mathbf{O}$ with the primary end of producing $\mathbf{E}$. There can be a corollary: as a consequence, I cannot act optimally when subjected to a severe deficiency of E. Finally, $\mathbf{I}$ is the most important side of the health triangle since it concurrently generates both energy $(\mathbf{E})$ and organization $(\mathbf{O})$. One phytoceutical that can increase all sides is Panax ginseng (Figure 2). 

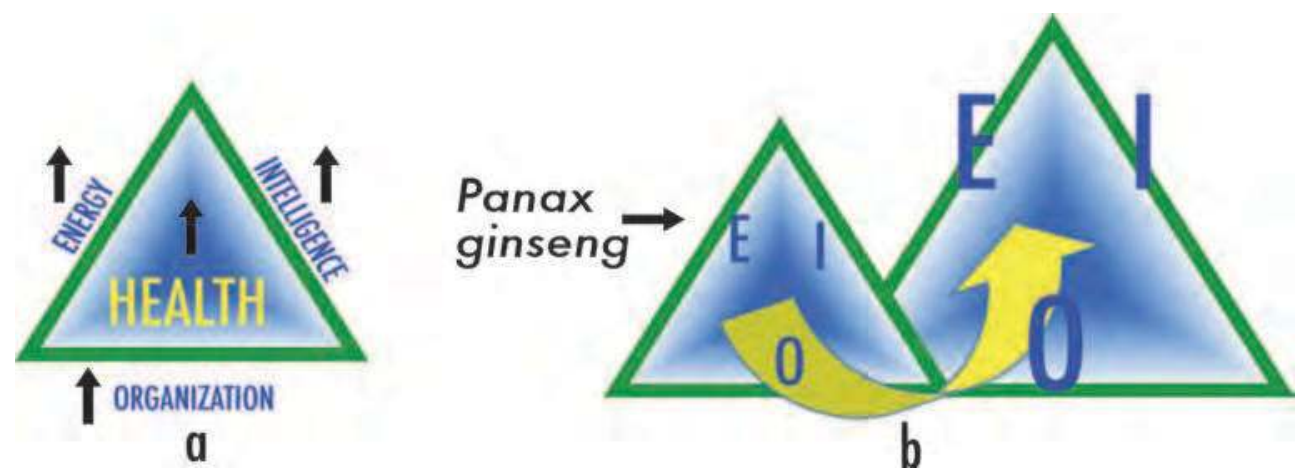

Fig. 2. (a) Example of a living system's health triangle. (b) Evolution from a given health situation and initial E, I, O triangle (left) to an improved E, I, O triangle (right). All sides are boosted due to negative entropy provided by Panax ginseng.

\subsubsection{Example of I, E and O increase by providing Panax ginseng}

Panax ginseng active principles are bonded to beta-adrenoceptors in the cellular membrane, triggering a secondary transmitting message system (cyclic AMP) which travels through a transducer pathway to the mitochondria to increase MDH, SDH and CTS activity, enzymes of the glycolisis or tricarboxylic acid cycle. ATP generation is thus increased, raising energy levels using glucose as fuel (Figure 3a). Thus, either the ATP/ADP ratio increase or the binding of ginsenosides to cell membrane receptors results in the KATP channel closure and insulin secretion (Rotsheyn \& Zito, 2004) (Figure 3b). Thus with the increase of energy a larger health triangle is obtained and the system's intelligence has acquired more capacity to organize. Panax ginseng provides an example of a remarkable phytomedicine which is capable of enhancing I, $\mathbf{E}$ and $\mathbf{O}$ simultaneously in the living system.

\subsection{Significance of the intelligence (I) within the systemic triangle. What is intelligence?}

The importance (and significance) of a system's intelligence is pivotal. How can this controversial and subjective concept be defined accurately? Olalde (2005a) confronted this dilemma by examining its definition in different fields. Table 1 lists different concepts of the term intelligence. 

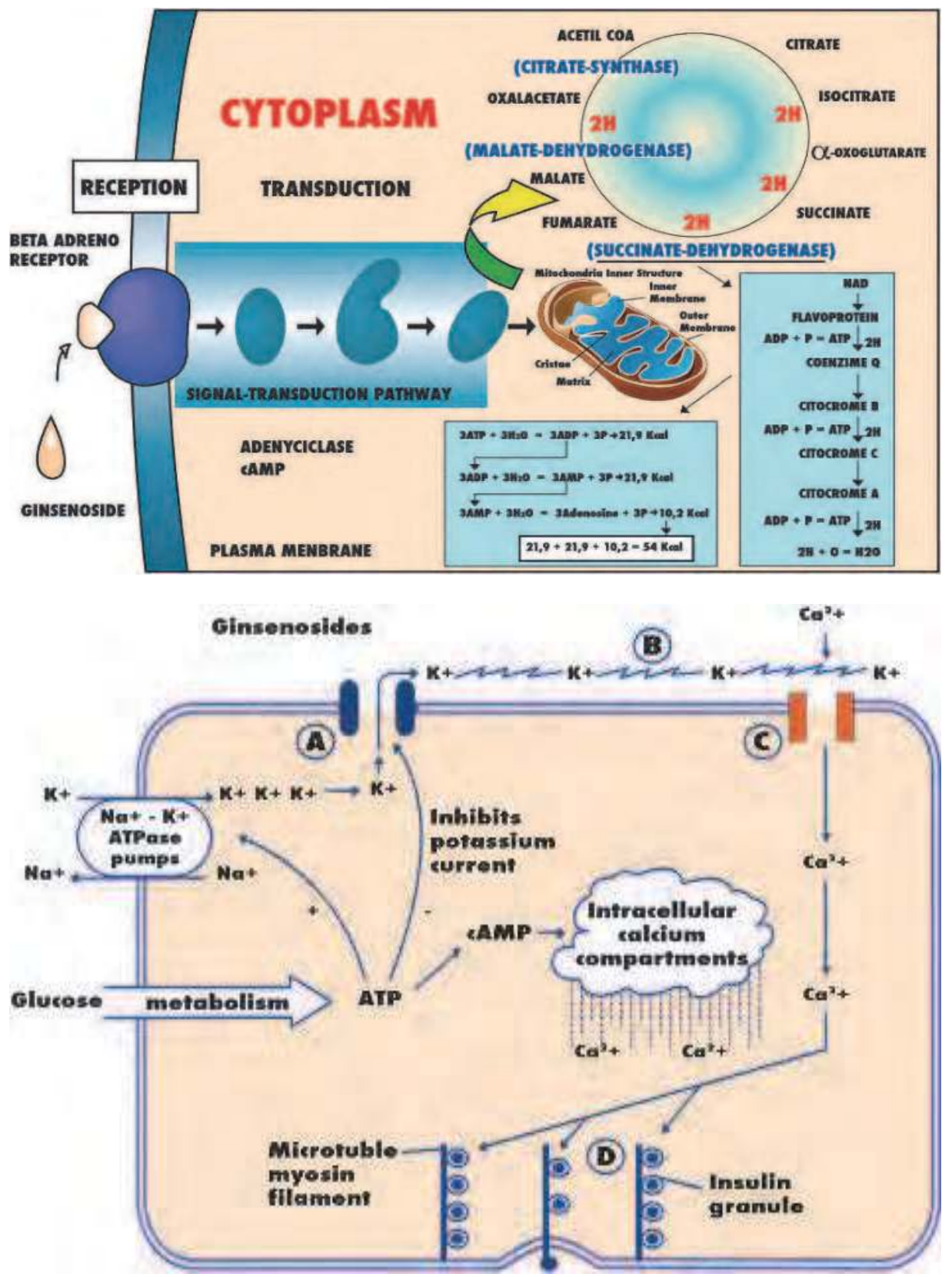

Fig. 3. a: (top) Panax intracellular action mechanism results in ATP synthesis stimulation, whose hydrolysis produces energy; b: (bottom) shows the Sodium-potassium ATP pump, illustrating ATP generation by administering ginsenosides in Panax ginseng to the Living System. 


\begin{tabular}{|c|c|c|}
\hline Domain & Reference & Definition of intelligence \\
\hline Cybernetics & Wiener, 1954 & $\begin{array}{l}\text { That whose core concepts are communication, } \\
\text { control and learning, by means of feedback } \\
\text { mechanisms. }\end{array}$ \\
\hline Physics & & Refers to regulation processes. \\
\hline Biophysics & & $\begin{array}{l}\text { Living system's endogenous regulation processes } \\
\text { effectively constitute intelligence. }\end{array}$ \\
\hline $\begin{array}{l}\text { Encyclopedic } \\
\text { Neufeldt V, } \\
\text { Guralnik D } \\
\text { (Eds) }\end{array}$ & $\begin{array}{l}\text { Webster's New } \\
\text { World } \\
\text { Dictionary(1988) }\end{array}$ & $\begin{array}{l}\text { (a) Ability to learn or understand from experience. } \\
\text { (b) Ability to acquire and retain knowledge. } \\
\text { (c) Ability to respond quickly and successfully to a } \\
\text { new situation. (d) Use of the faculty of reason in } \\
\text { resolving problems, directing conduct, etc. } \\
\text { effectively. (e) An intelligent spirit or being. } \\
\text { (f) Having knowledge, understanding or awareness. }\end{array}$ \\
\hline Multivarious & $\begin{array}{l}\text { World Wide } \\
\text { Web }\end{array}$ & $\begin{array}{l}\text { a) Ability of a system to process general information } \\
\text { to react appropriately to specific events; } \\
\text { b)The product of communication, resulting from the } \\
\text { collection, processing, integration, analysis, } \\
\text { evaluation and interpretation of available } \\
\text { information; c)Ability to acquire, store, retrieve, } \\
\text { process and generate information; d) Ability to learn } \\
\text { or understand or to deal with new or challenging } \\
\text { situations; e) Accumulation of experiences together } \\
\text { with the understanding of how these experiences } \\
\text { are connected; f)Capacity to act purposefully, to } \\
\text { think rationally, to communicate and to deal } \\
\text { effectively with his or her environment. } \\
\text { (g) Entity. (h) Emergent. }\end{array}$ \\
\hline
\end{tabular}

Table 1. Definitions of Intelligence

\subsubsection{Intelligence = Informational entity}

By analyzing common traits within the definitions given in Table 1, intelligence may be defined as that emergent informational entity, capable of learning, exerting control, emitting and receiving communication, handling energy flows, establishing feedback mechanisms and creating organization for survival. Emergent implies a higher level of intelligence of the whole, stemming from the intelligence of its parts. According to Laszlo, living systems are special third-stage systems, self-creating and self-replicating, that engender order out of chaos (Lazlo, 1987). However, Wiener states 'It is my thesis that the physical functioning of the living individual and the operation of some of the newer communications machines are precisely parallel in their analogous attempts to control entropy through feedback' (Wiener, 1954). The notion of intelligence that Olalde (2005) adopts is that of an informational entity, i.e. one which is emergent, can generate, process and exchange informational flows in order to control entropy. The concept of intelligence becomes more objective, and functional, when treated as an informational entity, one dependent on information exchange, which as we know has a thermodynamic interpretation. A change of entropy $(\triangle S)$ will produce a change or variation in information availability, and therefore a change in intelligence and 
order in the biological system. Any entity that can exchange informational flows can also generate changes of entropy. Thus, informational flow $\leftrightarrow$ change in entropy $\leftrightarrow$ change in intelligence. According to Stonier's proposed theory 'Pure energy can perform no 'useful' work (entropy reducing) without a concomitant input of information (Stonier, 1996). Conversely, all expenditures of energy lead to a reorganization of the universe, hence a change in its information status. Energy and information are inter-convertible'. This theory could provide additional support for the indispensable existence of an intelligent entity to handle information, since information without intelligence is without value. A possible corollary is: intelligence is that entity which can causatively alter entropy; and vice versa, entropy changes will also affect intelligence. Figure 4 shows an intelligent cell, an example of an informational entity capable of modifying entropy.

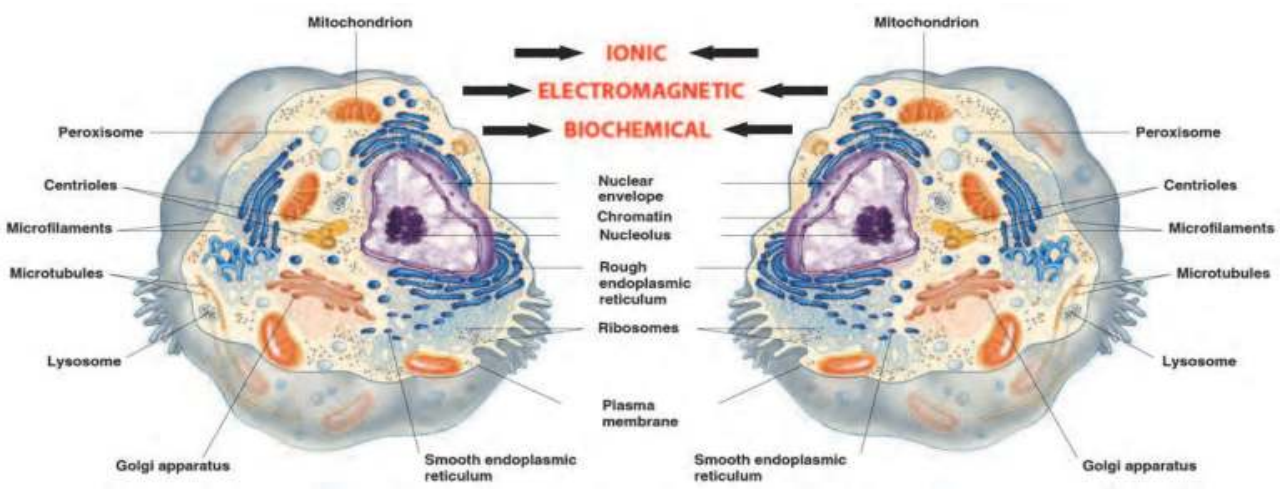

Fig. 4. A living system possesses intelligence and is capable, as human cells demonstrate, of an informational flow and exchange with other cells, organs and living systems. This communicational flow may have various 'vehicles' and 'avenues'.

\subsection{Synergy and informational systems}

Synergy is a quality of informational systems. It may be understood as emergent, i.e. the informational participation of each fractal member of the system in order to achieve a higher plateau of self-organization and survival (Haken, 2005). It can also be understood as the resulting effect that is greater than the algebraic sum of the parts. Synergy is an important characteristic of third-stage systems. The increase of energy availability within a third-stage, living, system also decreases its entropy, potentially generating an endogenous tendency for informational flow and a heightened intelligence; this in turn generates organization. By analogy, an increase of information will, on its own, raise intelligence which will positively influence energy and organization. In synergic terms, each of the three elements shown above has the capacity to affect (increase or decrease) the other two. Thus we derive the following synergic bi-conditionals, inherent to any third-stage system: survival potential = health $=\uparrow \mathrm{I} \leftrightarrow \uparrow \mathrm{E} \leftrightarrow \uparrow \mathrm{O} \leftrightarrow \mathrm{S} \downarrow$ and also demise $=$ sickness $=\downarrow \mathrm{I} \leftrightarrow \downarrow \mathrm{E} \leftrightarrow \downarrow \mathrm{O} \leftrightarrow \mathrm{S} \uparrow$.

\subsubsection{Informational substantiation of biological intelligence}

If there is communication, intelligence exists. Communication is a manifestation of intelligence. The existence of biochemical and bio-photonic communication in cells has been corroborated: biochemical communication, for example, between the neurological and 
immune systems, has been examined, among others, by Blalock (1989), Cavagnaro and Lewis (1989) and more recently Takeda and Okomura (2004) and Cooper (2004). The biophotonic communication concept was discovered by Alexander Gurwitsch in 1923, as an 'ultraweak' photon emission from living systems (Gurwitsch, 1991). About the same time, Frolich, father of the 'coherent' notion of living systems, discovered that nucleated cells are capable of picking up, storing and broadcasting information about the environment. The term biophotons '....denotes a permanent spontaneous photon emission from all living systems...' and explains '... biological phenomena like intracellular and intercellular communication, cell growth and differentiation, interactions among biological systems and microbial infections...' (Popp, 2003). Different scientific groups have confirmed the existence of (and suggested some uses for) this subtle photon emission in: Australia (Tilbary \& Quickenden, 1988; Trushin 2003), Japan (Kobayashi et al., 1996; Takeda et al., 1998), Poland (Slawinska \& Slawinski, 1987) and Germany (Popp, 2003). Other prominent scientists in the study of biophotons are Professor Voeikov (Voikov, 2003) and Dr. Albrecht-Buehler. This last sustains the thesis that cells are intelligent: 'capable of deriving abstract data and emitting near infrared signals' (Albrecht-Buehler, 1998, 1985).

\subsubsection{Biological Intelligence (BI)}

Intelligence is best measured by its manifestations. In structural terms, the BI is 'omnipresent' in the organism due to the intelligent nature of all cells (Gurwitsch, 1991); however, in functional terms, the $\mathrm{BI}^{\prime}$ s common denominator is comprised of the immune intelligence (II), cellular intelligence (CI) and biochemical (or neuroendocrine) intelligence (BI) (Blalock, 1989; Cavagnaro and Lewis, 1989; Cooper, 2004; Takeda and Okomura, 2004). The BI functions as an emergent informational entity, oriented towards survival, capable of auto-regulation, bidirectional communication, generating, processing and manipulating energy flows within the body. It is in charge of establishing, maintaining and restituting the organization. Figure 5 shows the interaction between neuroendocrine, immune and cellular intelligence. $\mathrm{CI}$ is the most important of $\mathrm{BI}^{\prime} \mathrm{s}$ constituents since it regulates genetics and metabolism of each and every organic cell and gives birth to the autonomous II and BI. These three elements also constitute a synergistic trio, since none of them can exist in the absence of another, due to essential feedback and information exchange amongst them (Blalock, 1989; Cavagnaro and Lewis, 1989; Cooper, 2004; Takeda and Okomura, 2004). BI could also be represented schematically as a triangle, since alterations to one side of a triangle always affect the other two. Its healing potential may be defined as the mathematical product of its immune, cellular and neuroendocrine state, i.e. BI (Healing Potential) $=\mathrm{II}^{\mathrm{I}} \times \mathrm{CI}^{\mathrm{I}} \times \mathrm{BI}^{\mathrm{I}}$. In consequence, it is possible to enhance BI by increasing any of its three essential components, for example with immune modulators (Bocharova et al., 2003; Geng et al., 2005; Kidd, 2000; Kohguchi et al., 2004; Kormosh et al., 2004). The opposite also holds true, a collapse of any component will affect the other two.

\subsection{From Systemic theory to Systemic medicine}

At the beginning of this section a question was posed. Was it possible to set up a system -or periodic table- where plants and other natural remedies could, according to their superior medicinal properties, be arranged to produce specific formulae that provide well-being for a given pathology? The Systemic Theory was set forth to provide an answer to this crucial question. Systemic Theory postulates that Health $(\mathrm{H})$ is directly proportional to the integrity 
of a living system's Energy (E), Bio-Intelligence (I) and Organization (O). Systemic Theory also established a common denominator to all sickness and ascertains the cause of all diseases to be an entropy increase: 'disorder augmenting within the biologically open system, stemming from energo-informational and organizational impacts, either of external or internal nature' (Olalde, 2005c). Systemic Therapeutics -or Medicine- should then include a negentropy supply to enhance the system's: energy-work capacity or E (i.e. physiological mechanisms associated with ATP synthesis, such as oxidative phosphorolysis, Krebbs cycle, $\beta$-oxidation etc.), its informational potential intelligence or I (i.e. the entity responsible for regulating neuroendocrine, biochemical, immune and cellular processes) and finally structure and functional organization or O. Systemic Medicine's (SM) treatment strategy is based on identifying and prescribing superior herbs-tonic or adaptogenic-or any nutraceuticals or medicine with potential to strengthen E, I, O by providing energo, informational and organizational aid to the overall network of intelligent cells and cell systems that constitute the body. The main premise proposes that when all three factors are brought back to ideal levels patients' conditions begin recovery to normal health. Table 2 provides a list of some $\mathrm{E}$, I and $\mathrm{O}$ ceuticals -or superior medicines- whose capacity to enhance $\mathrm{E}, \mathrm{I}$ and $\mathrm{O}$ have been studied and referenced.

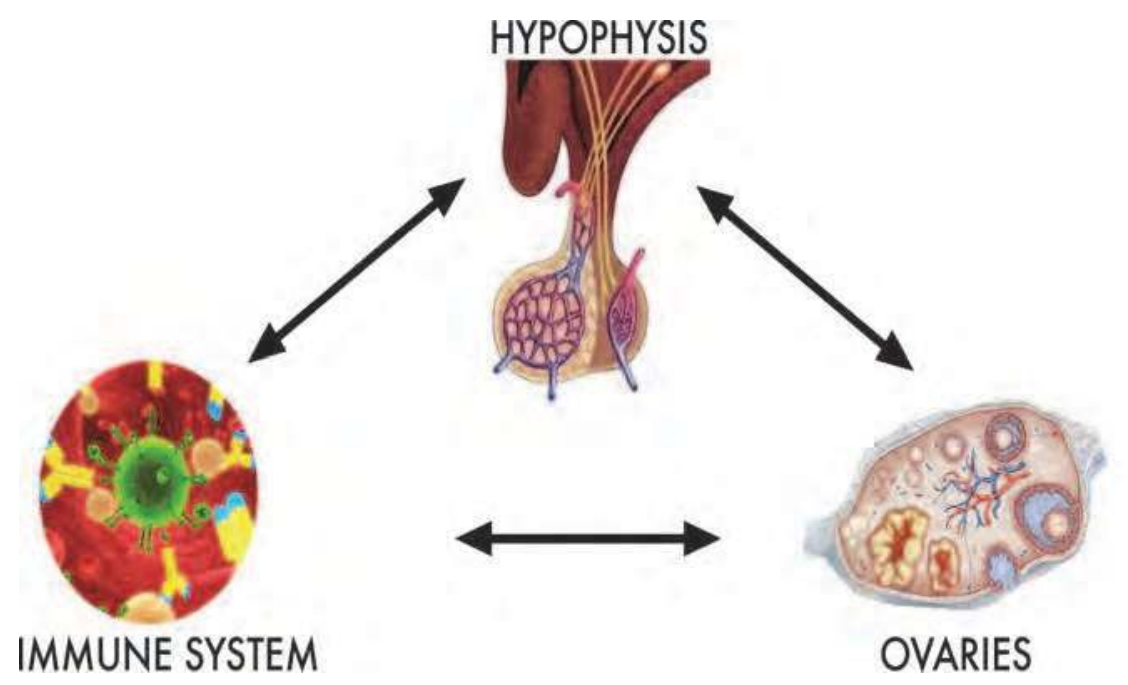

Fig. 5. An example of known cross-talk communication, bidirectional and bi-conditional, between the II (immune intelligence), $\mathrm{C}^{\mathrm{I}}$ (cellular intelligence) and $\mathrm{B}^{\mathrm{I}}$ (biochemical or neuroendocrine intelligence) in a human living system. 


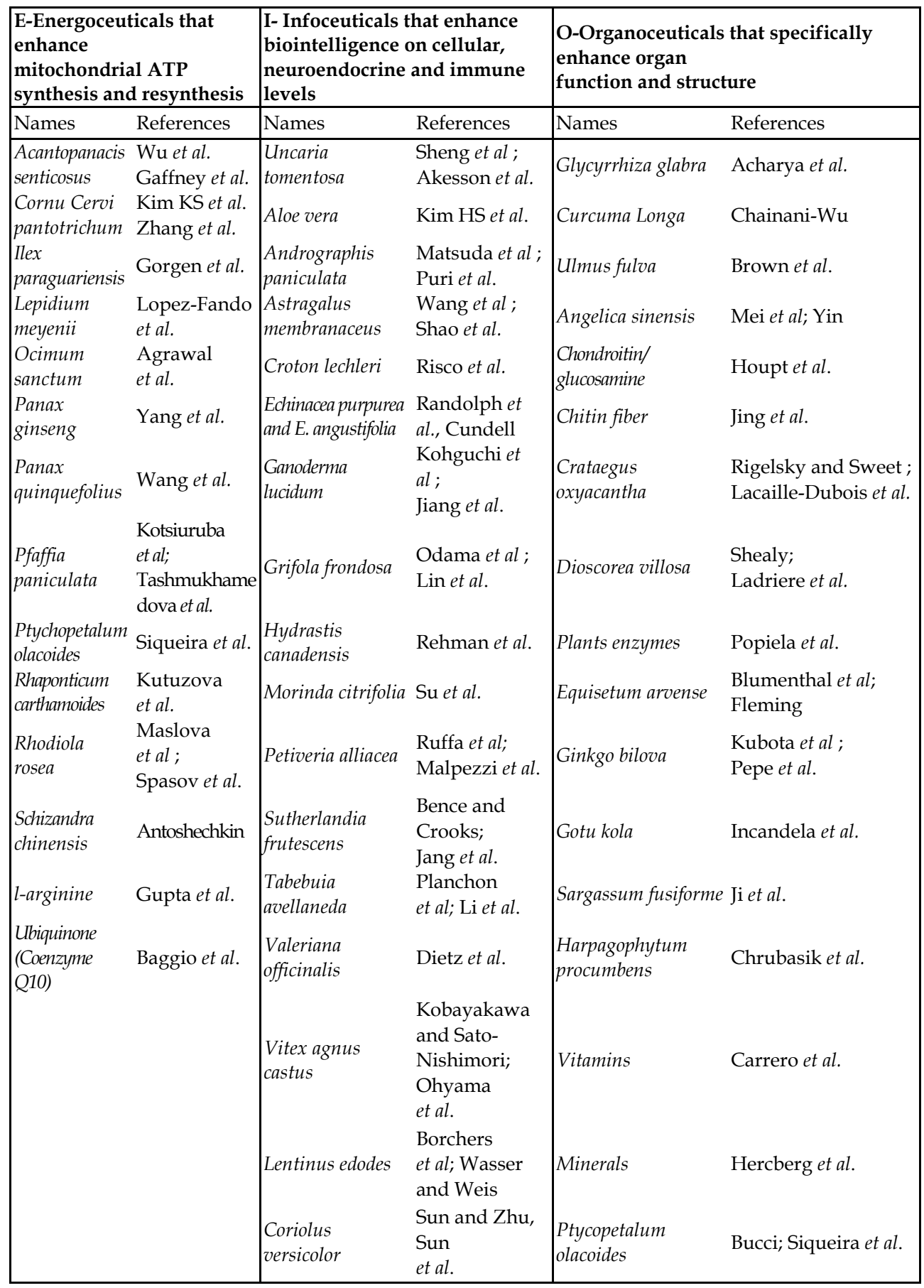




\begin{tabular}{|c|c|c|c|}
\hline $\begin{array}{l}\text { E-Energoceuticals that } \\
\text { enhance } \\
\text { mitochondrial ATP } \\
\text { synthesis and resynthesis }\end{array}$ & $\begin{array}{l}\text { I- Infoceuticals that enhance } \\
\text { biointelligence on cellular, } \\
\text { neuroendocrine and immune } \\
\text { levels }\end{array}$ & \multicolumn{2}{|c|}{$\begin{array}{l}\text { O-Organoceuticals that specifically } \\
\text { enhance organ } \\
\text { function and structure }\end{array}$} \\
\hline & $\begin{array}{l}\text { Cordyceps } \\
\text { sinensis }\end{array}$ & $\begin{array}{l}\text { Pygeum africanum } \\
\text { Rhamnus purshiana } \\
\text { Ruscus aculeatus } \\
\text { Salix alba } \\
\text { Sena alejandrina } \\
\text { Serenoa repens } \\
\text { Silibum marianum } \\
\text { Smilax china } \\
\text { Tribulus terrestris } \\
\text { Vaccinium } \\
\text { myrthillus } \\
\text { Viburnum spp. } \\
\text { Zingiber officinalis }\end{array}$ & $\begin{array}{l}\text { Freeman and } \\
\text { Solomon, } \\
\text { Santa Maria } \\
\text { Margalef et al. } \\
\text { Ma et al. } \\
\text { Redman, Bouaziz et } \\
\text { al. } \\
\text { Chrubasik et al. } \\
\text { Franz } \\
\text { Goldmann et al ; } \\
\text { Iguchi } \\
\text { Halim et al; } \\
\text { Chrungoo et al. } \\
\text { Lee et al. } \\
\text { Hong et al. } \\
\text { Zaragoza et al; } \\
\text { Savickiene et al. } \\
\text { Calle et al. } \\
\text { Young et al. }\end{array}$ \\
\hline
\end{tabular}

Table 2. Examples of ceuticals -or superior medicines- whose capacity to enhance E, I and O has been studied and referenced

\subsubsection{The case for a systemic complex herbal formulation: Circulat}

Thus a composition was formulated taking into account the precepts established in both the Systemic Theory and Medicine. Circulat is a systemic standardized HPLC fingerprinted plant extract combination which consists of: 1) Energy plants (E) associated with ATP synthesis (such as tricarboxylic acid cycle, oxidative phosphorylation, etc) which boost the system's energy-work capacity: Eleutherococcus senticosus, Leuzea carthamoides, Panax ginseng, Panax quinquefolius, Pfaffia paniculata, and Rhodiola rosea; 2) Bio-Intelligence plants (I) which modulate the neuroendocrine and immunological systems and cellular processes enhancing the system's informational potential intelligence (specifically in this formulation they increase insulin production, insulin receptor sensitivity, improve intracellular glucose uptake, contribute antimicrobial properties, improve inflammation as well as humoral and unspecific cellular immunity): Echinacea angustifolia, Echinacea purpurea, Ganoderma lucidum, Grifola frondosa, Hydrastis canadensis, Petiveria alliacea, Sutherlandia frutescens, and Uncaria tomentosa; and finally 3) Organizational plants (O) which enhance the structure and functional organization of specific organs supporting overall health (in Circulat's case, among others, promoting vasodilatation, tissular perfusion improvement, regeneration and skin scarring): Angelica sinensis, Crataegus oxyacantha, Croton lechleri, Ginkgo biloba, Hydrocotyle asiatica, Ruscus aculeatus, Vaccinium myrthillus, and Tabebuia avellanedae. Although some of these plants act predominantly over one of the factors that influence individual's overall health (E, I, and $\mathrm{O}$ ), some act over more than one factor (i.e. Panax and Ganoderma). Please, see Table 3. 


\begin{tabular}{|c|c|}
\hline \multicolumn{2}{|l|}{ Energy plants } \\
\hline $\begin{array}{l}\text { Panax ginseng } \\
\text { and } \\
\text { Panax } \\
\text { quinquefolius }\end{array}$ & $\begin{array}{l}\text { Increases ATP synthesis by stimulating activities of enzymes related to } \\
\text { tricarboxylic acid cycle and oxidative-phosphorylation, such as succinate } \\
\text { dehydrogenase, malate dehydrogenase, citrate synthetase, cytochrome oxidase, } \\
\text { and phosphorylase (Wang et al;, 2003). }\end{array}$ \\
\hline $\begin{array}{l}\text { Eleutherococcus } \\
\text { senticosus }\end{array}$ & $\begin{array}{l}\text { Increases ATP synthesis by stimulating activities of enzymes related to } \\
\text { tricarboxylic acid cycle, such as succinate dehydrogenase and malate } \\
\text { dehydrogenase (Sugimura et al., 1989). }\end{array}$ \\
\hline $\begin{array}{l}\text { Leuzea } \\
\text { carthamoides } \\
\text { and Pfaffia } \\
\text { paniculata }\end{array}$ & $\begin{array}{l}\text { Increase ATP synthesis, stimulates activities of enzymes related to tricarboxylic } \\
\text { acid cycle, such as succinate dehydrogenase. Also, normalize NADH } \\
\text { dehydrogenase activity, enzyme related to the oxidative phosphorylation } \\
\text { processes, contributing to buildup the electrochemical potential used to produce } \\
\text { ATP (Tashmukhamedova et al., 1986). }\end{array}$ \\
\hline Rhodiola rosea & $\begin{array}{l}\text { Activates ATP synthesis/resynthesis in mitochondria, stimulates reparative } \\
\text { energy processes (Abidov et al.; 2003). }\end{array}$ \\
\hline \multicolumn{2}{|c|}{ Anti-inflamatory-Inmunostimulant plants (Immune Intelligence) } \\
\hline $\begin{array}{l}\text { Tabebuia } \\
\text { avellanedae }\end{array}$ & $\begin{array}{l}\text { Inhibits NO, iNOS, COX-2 and PGE(2) release. Attenuates expression of } \\
\text { mRNA and pro-inflammatory cytokines proteins, such as interleukin (IL)- } \\
\text { 1beta, IL-6 and tumor necrosis factor (TNF)-alpha. Suppresses NF-kappaB } \\
\text { activation by blocking IkappaBalpha degradation and downregulating ERK, } \\
\text { p38 mitogen-activated protein kinase (MAPK) and Akt pathway (Moon et al., } \\
\text { 2007). }\end{array}$ \\
\hline $\begin{array}{l}\text { Echinacea } \\
\text { angustifolia } \\
\text { and Echinacea } \\
\text { purpurea }\end{array}$ & $\begin{array}{l}\text { Due to: a) reduction of IL-2 production (Sasagawa et al., 2006); and b) down- } \\
\text { regulation of COX-2 expression (Groom et al, 2007). Immune-stimulant due } \\
\text { to: a) macrophage phagocytosis stimulation (Raso et al., 2002); b) cellular } \\
\text { immunity and neutrophils' phagocytosis stimulation. Increases number of } \\
\text { leucocytes and lymphocytes, especially T lymphocytes (Jurkstiene et al., } \\
\text { 2004); c) Significant enhancement of IgM specific antibody forming cell } \\
\text { response (Freier et al., 2003); d) complement properdin increases (Kim et al., } \\
2002 \text { ). }\end{array}$ \\
\hline $\begin{array}{l}\text { Ganoderma } \\
\text { lucidum }\end{array}$ & Promotes phagocytosis and cytotoxicity of macrophages (Zhu et al., 2007). \\
\hline Grifola frondosa & $\begin{array}{l}\text { Antiinflamatory: because it inhibits cyclooxygenase (COX) enzyme (Zhang et al., } \\
\text { 2002). Inmunoestimulant because it: Increases IL-10, NO and IFN-gamma. } \\
\text { Enhances both the innate and adaptive arms of the immune response (Kodama et } \\
\text { al., 2004). }\end{array}$ \\
\hline $\begin{array}{l}\text { Hydrastis } \\
\text { canadensis }\end{array}$ & $\begin{array}{l}\text { Antiinflamatory due to a prostaglandin E2 production reduction as a result of } \\
\text { AP-1 binding inhibition (Kuo et al., 2004). }\end{array}$ \\
\hline $\begin{array}{l}\text { Sutherlandia } \\
\text { frutescens }\end{array}$ & $\begin{array}{l}\text { Antiinflamatory, inhibits COX-2 and through activation of activator protein-1 } \\
\text { (AP-1) (Kundu et al., 2005). }\end{array}$ \\
\hline $\begin{array}{l}\text { Uncaria } \\
\text { tomentosa }\end{array}$ & $\begin{array}{l}\text { Antiinflamatory achieved by a TNFalpha and PGE2 production inhibition } \\
\text { (Piscoya et al., 2001). } \\
\text { Inmunostimulant because it stimulates macrophage phagocytosis (Groom et al., } \\
\text { 2007). }\end{array}$ \\
\hline $\begin{array}{l}\text { Panax ginseng } \\
\text { and } \\
\text { Panax } \\
\text { quinquefolius }\end{array}$ & $\begin{array}{l}\text { Antiinflamatory: It inhibit iNOS and COX-2 protein expression, and activates the } \\
\text { transcription factor, NF-kappaB (Park et al., 2004). Inmunomodulator: Increases } \\
\text { neutrophiles and macrophages phagocytosis, stimulates humoral and cell } \\
\text { immune factors and induces important regulating cytokins -interferone gamma } \\
\text { and tumor necrosis factor (Smolina et al., 2001). }\end{array}$ \\
\hline
\end{tabular}




\begin{tabular}{|c|c|}
\hline $\begin{array}{l}\text { Eleutherococcus } \\
\text { senticosus }\end{array}$ & Inmunoestimulant: Activates B cells and macrophages (Han et al., 2003). \\
\hline Pfaffia paniculata & Increases macrophage activity (Pinello et al., 2006) \\
\hline Angelica sinensis & $\begin{array}{l}\text { Immunomodulatory activity by regulating expression of Th1 and Th2 related } \\
\text { cytokines (Yang et al., 2006). }\end{array}$ \\
\hline \multicolumn{2}{|c|}{ Hypoglycemic plants (Biochemical Intelligence) } \\
\hline Panax ginseng & $\begin{array}{l}\text { Reduces blood glucose levels (Reay et al., 2005). Inhibits glycated hemoglobin } \\
\text { formation (Bae and Lee, 2004). }\end{array}$ \\
\hline $\begin{array}{l}\text { Panax } \\
\text { quinquefolius }\end{array}$ & Decreases postprandial glicemia (Vuksan et al., 2000) \\
\hline $\begin{array}{l}\text { Eleutherococcus } \\
\text { senticosus }\end{array}$ & $\begin{array}{l}\text { Lowers circulating glucose and lipids, and enhances insulin action (Park et al., } \\
\text { 2006). } \\
\text { Improves insulin sensitivity (Liu et al., 2005). }\end{array}$ \\
\hline $\begin{array}{l}\text { Ganoderma } \\
\text { lucidum }\end{array}$ & $\begin{array}{l}\text { Stimulates glucose uptake, stimulating the activity of phosphatidylinositol 3- } \\
\text { kinase, Protein kinase B, AMP-activated protein kinase which are regulatory } \\
\text { molecules in the glucose uptake pathway (Jung et al., 2006). Lowers glucose } \\
\text { levels through insulin-releasing activity due to facilitation of Ca2+ inflow to } \\
\text { pancreatic beta cells (Zhang and Lin, 200 4). }\end{array}$ \\
\hline Grifola frondosa & $\begin{array}{l}\text { Decreases fasting plasma glucose levels and increases insulin sensitivity (Hong et } \\
\text { al., 2007). }\end{array}$ \\
\hline $\begin{array}{l}\text { Hydrastis } \\
\text { canadensis }\end{array}$ & $\begin{array}{l}\text { Stimulates glucose uptake via: increasing GLUT1 activity and adenosine } \\
\text { monophosphate-activated protein kinase and acetyl-coenzyme A carboxylase } \\
\text { phosphorylation (Zhou et al., 2007); and through AMP-AMPK-p38 MAPK } \\
\text { pathway (Cheng } \text { et al., 2006). Inhibitor of aldose reductase (Feng } \text { et al., 2005). }\end{array}$ \\
\hline Petiveria alliacea & $\begin{array}{l}\text { Decreases: a) blood glucose levels (Lores and Cires Puyol, 1990); and b) fasting } \\
\text { glucose, post-prandial glucose levels, and hemoglobin A1c in type } 2 \text { diabetic } \\
\text { patients, by acting downstream in the insulin signaling pathway (Kim et al., } \\
\text { 2007). }\end{array}$ \\
\hline $\begin{array}{l}\text { Sutherlandia } \\
\text { frutescens }\end{array}$ & $\begin{array}{l}\text { Normalizes insulin levels and increases glucose uptake (Chadwick et al., 2007). } \\
\text { Decreases fasting glucose, post-prandial glucose levels, and hemoglobin A1c in } \\
\text { type } 2 \text { diabetic patients, by acting downstream in the insulin signaling pathway } \\
\text { (Kim } \text { et al., 2007). }\end{array}$ \\
\hline \multicolumn{2}{|c|}{ Antimicrobial and Skin Scarring plants (Organization) } \\
\hline $\begin{array}{l}\text { Tabebuia } \\
\text { avellanedae }\end{array}$ & $\begin{array}{l}\text { Antibacterial activity against methicillin-resistant S. aureus, S. epidermidis and } \\
\text { S. haemolyticus strains, being the two last ones hetero-resistant to vancomycin } \\
\text { (Pereira et al., 2006). }\end{array}$ \\
\hline Petiveria alliacea & Broad spectrum of antimicrobial activity (Kim et al., 2006). \\
\hline $\begin{array}{l}\text { Hydrastis } \\
\text { canadensis }\end{array}$ & Broad spectrum of antimicrobial activity (Scazzocchio et al., 2001). \\
\hline $\begin{array}{l}\text { Sutherlandia } \\
\text { frutescens }\end{array}$ & $\begin{array}{l}\text { Antibacterial against against S. aureus, E. faecalis and E. coli (Katerere and Elfo, } \\
\text { 2005). }\end{array}$ \\
\hline $\begin{array}{l}\text { Uncaria } \\
\text { tomentosa }\end{array}$ & $\begin{array}{l}\text { Antimicrobial activity on Enterobacteriaceae, S. mutans and Staphylococcus spp. } \\
\text { (Ccahuana-Vasquez et al., 2007). }\end{array}$ \\
\hline Croton lechleri & $\begin{array}{l}\text { Potent anti-bacterial activity (Chen et al., 1994). Cicatrizant effect because it } \\
\text { increases the migration of skin fibroblasts (Vaisberg et al., 1989). }\end{array}$ \\
\hline $\begin{array}{l}\text { Hydrocotyle } \\
\text { asiatica }\end{array}$ & $\begin{array}{l}\text { Promotes fibroblast proliferation and extracullar matrix synthesis in wound } \\
\text { healing because it upregulates } 54 \text { genes with known functions for cell } \\
\text { proliferation, cell-cycle progression and synthesis of the extracellular matrix ( } \mathrm{Lu} \\
\text { et al., 2004). }\end{array}$ \\
\hline
\end{tabular}

Table 3. Circulat's E, I and O -referenced- components and action mechanisms. 


\section{Assessment of Circulat's capability to modulate diabetes related gene expression levels in cultured human fibroblasts}

Circulat had provided an auspicious early clinical proof of its effectiveness (Olalde et al., 2005) in the treatment of Diabetic Foot -a circulatory disease. However, a pending assignment was to confirm its molecular activity. One way to test this characteristic was to identify the modulating and/or synergistic roles that such formulation could have in diseases such as Diabetes Mellitus (I and II). The study called 'Analysis of the Effects of the Herbal preparation Circulat on Gene Expression Levels in Cultured Human Fibroblasts' was carried out in cooperation with the Pennsylvania State University, Department of Genetics (Antoshechkin et al., 2007).

\subsection{Materials and methods}

Circulat whole composition -a lyophilized ethanol/water extract of 22 known medical plants in different ratios- and its three E, I and O fractions (or components 1, 2 and 3) identical and in the same proportion as in the formula were tested using microarray analysis using the Affymetrix GeneChip Human Genome U133 Plus 2.0 arrays that provide full genomic coverage and contain probes for more than 47000 unique transcripts corresponding to more than 38500 human genes. This allowed monitoring simultaneously the expression levels of practically all annotated genes of the human genome in an unbiased manner. Following hybridization and scanning, raw data in the form of image files were converted to gene expression files using the Affimetrix GeneChip Operating Software (GCOS) which utilizes MAS 5.0 algorithm for data normalization, background subtraction, and the estimation of nonspecific binding, calculation of detection p-values and generation of presence calls. Two-tailed Taylor Student's t-test assuming unequal sample variance was used to identify genes that displayed significant changes in the mean expression levels between control and each of the treated samples with the t-test-p value less than 0.05 and the mean fold change of at least 2 . By comparing up and down regulated genes in each individual fraction and whole Circulat, additional genes were identified that were regulated between 1.5 and 2 fold in the whole preparation and followed the same trend as in individual fractions, where they were up -or downregulated by at least 2 fold.

\subsubsection{Results}

The Affymetrix GeneChip represents state of the art in microarray design and features both perfectly matched and off-by-one probes that together with sophisticated processing algorithm allow distinguishing precisely between specific and non-specific hybridization signals. It has been proven to produce highly reliable data, which in combination with the high quality of starting RNA and sufficient number of replicates virtually eliminates falsepositives. Significant changes in the mean expression levels between control and treated samples resulted in a list of 87, 96, 24 and 187 genes (probes) that were significantly up or down- regulated upon treatment with components 1, 2, 3 and whole Circulat, respectively. The genes regulated by the individual components and the whole Circulat formula showed a significant overlap, as expected. More than $80 \%$ of the genes affected by the individual fractions were also affected by the whole preparation. Analysis of the data for each of the three components also identifies a sizable number of genes (23) that 
did not show up in the whole Circulat analysis. On the other hand, 55 genes the expression of which changed significantly after Circulat treatment were not observed in any of the three fractions. The regulation of these 32 genes by Circulat is more likely due to the interaction between active ingredients of the three components that produce a synergistic effect on gene regulation. Taken together the data demonstrates that: 1) Treatment of human fibroblast cells with either Circulat or its components result in marked changes in gene expression patterns; 2) Significant interactions between the active ingredients of Circulat exist resulting in a more complex pattern of gene expression in the complete preparation when compared with those of the isolated components which can be understood to be synergistic. Figure 6 .

\section{The formulation modulates 32 additional genes than the sum of formulas' individual fractions}

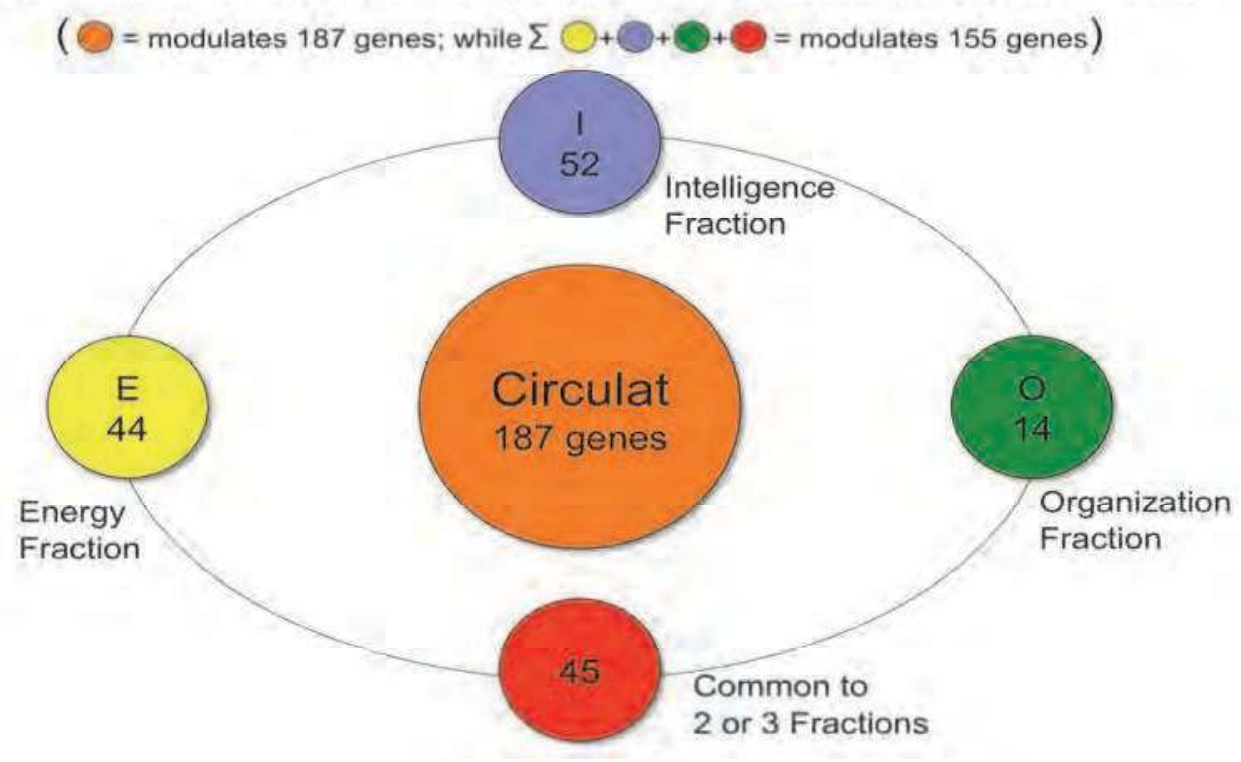

Fig. 6. Circulat -as a whole- modulates 187 genes, 32 genes more than the sum of the E, I and $\mathrm{O}$ fractions that make it up.

\subsubsection{Analysis of processes and pathway affected by circulat}

Examination of the biological process subset of Gene Ontology (GO) terms (Ashburner et al., 2000) associated with each gene and their distribution revealed that genes affected by Circulat are involved in a variety of cellular processes including protein, nucleic acid, lipid and carbohydrate metabolism, regulation of transcription, response to endogenous and external stimuli and stress, signal transduction and cell communication, cell growth and proliferation, development, protein modification and biosynthesis, generation of precursor metabolites and energy, etc. The broad spectrum of processes potentially regulated by Circulat (Figure 7) is consistent with the established ability of Circulat to prevent the development of severe manifestations of type 2 diabetes, which is a complex syndrome 
involving many intracellular signaling cascades and pathways as well as cell-cell interactions.

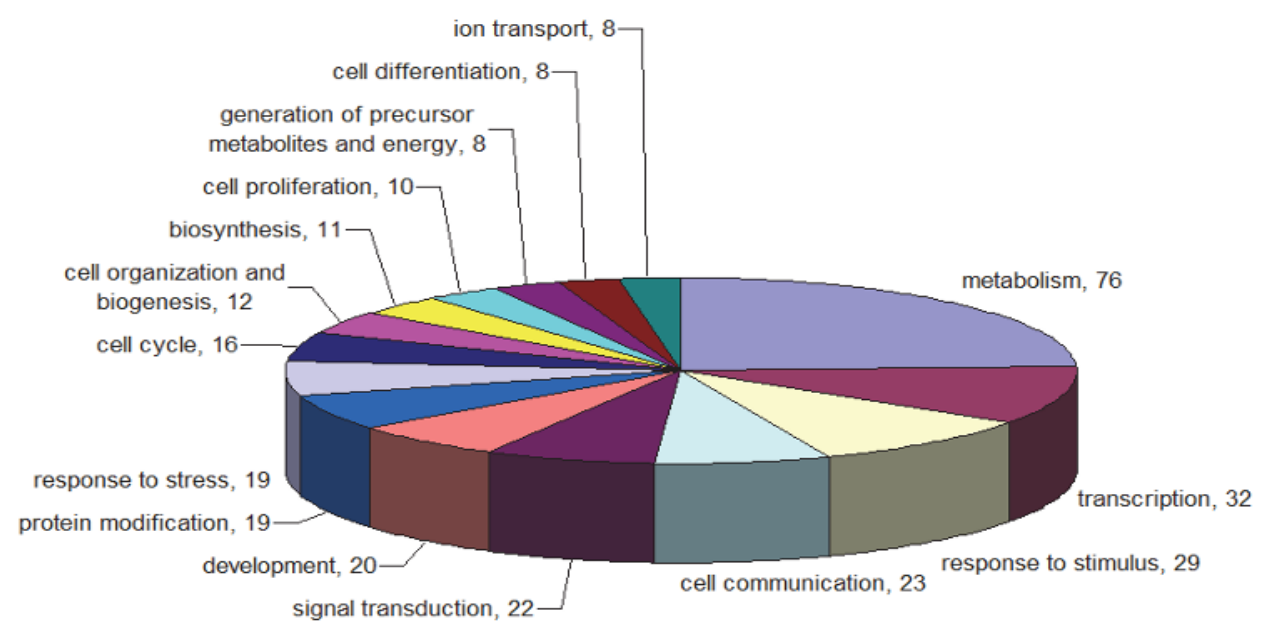

Fig. 7. Number of genes involved in a particular process that were affected by treatment is indicated. Numbers correspond to the number of probes that are annotated within a particular process.

Many of those pathways are involved in energy generation and are regulated on both transcriptional and post-transcriptional levels in response to endogenous or exogenous stimuli. A high proportion of genes identified in the experiments are implicated in the regulation of transcription (e.g.ATF3, Kruppel-like factor 4 Zinc finger protein 117, SATB2), energy production and glucose metabolism (thioredoxin domain containing 11, ATP5F1, PGK1) and signal transduction corroborating the hypothesis that Circulat is capable of normalizing molecular processes perturbed in the course of type 2 diabetes. Specially, Circulat proves to be effective in the treatment of diabetic gangrene, which is often resistant to common treatments. Previous studies have suggested that impaired fibroblast function such as proliferation, cell migration, growth factor production and collagen synthesis may be part of the mechanism of diabetic necrotic damage. Fibroblasts are central to the processes of extracellular matrix deposition and remodeling that take place during tissue repair process. It functions both as a synthetic cell, depositing a collagen-rich matrix, and a signaling cell, secreting the growth factors important for cellcell communication during the tissue repair process. Many Circulat-regulated genes play roles in signal transduction and cell communication (ADAM32, TRIO, RAB7), response to endogenous and exogenous stimuli, an essential component in wound healing (FANCB, SLC19A2, C4A), growth factor-mediated signaling and cell motility (IL6, CXCL2, VIM), cell proliferation and biosynthesis (PBEF1, ABP1, PTGS2) corroborating Circulat's effectiveness in tissue repair. Furthermore, tissue remodeling involves both the generation of new cell types as well as regulated cell death, and several genes important for cell differentiation and apoptosis were identified in the experiment (KLF4, RTN1, 
PDCD5). It was also observed that significantly down-regulated genes are enriched for members of signaling cascades known to regulate transcription and progression through the mitotic cycle such as FOSB, SNF1-like kinase and PRKAR1A (cAMP-dependent protein kinase regulatory subunit), cyclin L2. Up-regulated genes also contain a high number of genes involved in progression through the cell cycle as well as in DNA damage response, including cyclin M. GTSE1, FANCB and BR1P1 (BRCA1 interacting protein C-terminal helicase 1), cyclin-dependent kinase inhibitor C2 (CDKN2C). A number of transcription factors and members of protein degradation machinery (ubiquitin-conjugating enzyme E2E 3, Ring finger and WD repeat domain 2) are also present among those genes. Data suggest that one of the reasons for Circulat's therapeutic effects is derived from its ability to stimulate cellular activities that respond to internal and external stress by slowing or arresting the cell cycle to allow repair of cellular components that could be damaged in the course of the disease, such as DNA and proteins, to be carried out by repair enzymes.

\subsection{Discussion}

It was shown that four genes, IL6, HMGA1, SLC19A2 and C4A that are known to be involved in the development and progression of diabetes are strongly regulated by Circulat. This not only validated the experimental approach, but also allowed for the first time to suggest an explanation for the clinical effectiveness of Circulat at the molecular level. The role of interleukin-6 (1L6) in diabetes type 1 and 2 is thoroughly documented (for a review see Kristiansen and Mandrup-Poulsen, 2005). Low-grade inflammation has been proposed to be involved in the pathogenic processes causing type 2 diabetes and inflammatory mechanisms are known to play a key role in the pathogenesis of type 1 diabetes. As a mediator of inflammation, IL6 is thought to be involved in events causing both types of the disease when present at elevated levels. In addition, IL6 can also regulate glucose homeostasis and metabolism directly and indirectly by both increasing the destruction of insulin producing $\beta$-cells by promoting apoptosis and playing a role in mounting insulin resistance in skeletal muscle, adipocytes and other tissues. Since elevated levels of IL6 are the known predisposition factors for development of diabetes, reduction of IL6 concentration should have the opposite therapeutic effect. The results demonstrate that Circulat treatment reduces IL6 expression more than two fold. $(0.42, p$ $=0.002$ ) providing a solid link between the molecular events and the clinical manifestations taking place upon Circulat treatment. HMGA1 expression levels were elevated by more than two fold $(2.07, \mathrm{p}=0.02)$ in samples treated with Circulat. Mutations in this small nuclear protein that acts as an architectural transcription factor have been detected in individuals suffering from type 2 diabetes (Foti et al., 2005). This correlated with the insulin receptor's expression reduction and consequent development of insulin resistance. Deletion of HMGA1 gene in mice resulted in almost a complete loss of insulin receptor expression, development of insulin resistance and type 2 diabetes-like symptoms. HMGA1 thus plays a crucial role in glucose homeostasis and its increased expression promoted by Circulat may counteract deleterious effects caused by the loss of insulin receptor observed in type 2 diabetic patients. Two other genes, SLC19A2 and C4A, that are affected by Circulat $(0.43, p=0.03$ and $0.48, p=0.02$, respectively) have also been unequivocally linked to diabetes. SLC19A2 encodes a thiamine transporter protein and causes thiamine-responsive megaloblastic anemia (TRMA) also known as Rogers 
syndrome, when mutated (Labay et al., 1999). Diabetes (both type 1 and 2) is the primary disease that defines the syndrome. C4A encodes the acidic form of complement factor 4 , part of the classical activation pathway. Deficiency of this protein is associated with systemic lupus erythematosus and type 1 diabetes mellitus (Palsdottir et al., 1983). While no direct link between $\mathrm{C} 4 \mathrm{~A}$ and diabetes type 2 has been found thus far, it has been suggested that the two types of the disease share many of the underlying processes thus making C4A involvement in type 2 diabetes a real possibility. Precise molecular mechanisms of SLC19A2 and C4A involvement in the disease development are not established as well as for IL6 and HMGA1. Nevertheless, their link to diabetes is indisputable and the ability of Circulat to influence their expression suggests additional possible Circulat action mechanisms. Analysis of genes affected by Circulat also reveals that 26 of them have been implicated in many human diseases other than diabetes. It is possible that some of those diseases and syndromes could be caused by misregulation of the same (or similar) genetic pathways that are perturbed in type 2 diabetes, which could be one of the explanations for this observation. On the other hand, it raises an exciting possibility that Circulat could be effective for treatment of conditions other than type 2 diabetes. Finally, analysis of genes regulated by the total Circulat and its individual components demonstrated the existence of significant interactions between the active ingredients of Circulat suggesting that the full therapeutic effects can only be achieved by administration of the complete preparation.

\subsection{Significance of gene expression analyses}

The application of full-genome expression analyses to phytopharmacology opens new horizons for carrying out scientific studies of herbal remedies and integration of herbalbased treatments into mainstream medicine. Using this approach, the physiologically active fractions of effective herbal extracts can be isolated and their specific activities can be determined. Such separation of different activities of a particular extract may enable researchers to selectively regulate the expression of specific genes (or gene groups) by varying the composition of the herbal preparation. It is likely therefore, that expressionprofiling-based approaches to studies of herbal medicines will become standard in phytopharmacology in the near future. This section, explained Circulat's molecular modulating capabilities. Section 4 will examine its clinical effectiveness through a diabetic foot study synthesis.

\section{Circulat's therapeutic properties in diabetic foot: Synthesis}

The World Health Organization estimated that more than 220 million people worldwide have diabetes (WHO, 2011). This number was likely to more than double by 2030. Diabetic foot ulcers are one of the most frequent complications of this disease. The prevalence of diabetic foot ulcers has been estimated, at the time of the study, between 2.2 and $15 \%$. Differences being attributed to risk factor diversity: ethnicity, age, sex, education level, health service quality, and others (Table 4). Diabetic foot ulcers represent a large emotional and economic burden on patients and caregivers, as well (Gulam-Abbas et al, 2002). Foot complications are caused by diabetic neuropathy or peripheral ischemic vessel disease or a combination of both (Ratzmann et al, 1994) and are the most frequent reason for hospitalization in patients with diabetes. 


\begin{tabular}{|c|c|c|}
\hline $\begin{array}{c}\text { Diabetic foot ulcers } \\
\text { prevalence }\end{array}$ & Country & References \\
\hline $2.2 \%$ & UK & Abbott et al, 2002 \\
\hline $3-8 \%$ & Sweden & Apelqvist and Larsson, 2000 \\
\hline $4.6 \%$ & Kenya & Nyamu et al, 2003 \\
\hline $5.3-5.6 \%$ & Finland & Lehto et al, 1996 \\
\hline $5.4-7.3 \%$ & USA & Moss et al, 1996 \\
\hline $10.2 \%$ & Sri Lanka & Fernando, 1996 \\
\hline $15 \%$ & Tanzania & Gulam-Abbas et al, 2002 \\
\hline
\end{tabular}

Table 4. Examples of diabetic foot ulcer prevalence by country and references

Diabetic foot complications are the most common cause of non-traumatic lower extremity amputations in the industrialized world. The risk of lower extremity amputation is 15 to 46 times higher in diabetics than in persons who do not have diabetes mellitus (Armstrong, 1997). Approximately $40-60 \%$ of all lower extremity amputations are performed in patients with diabetes. More than $85 \%$ of these amputations are precipitated by a foot ulcer deteriorating to deep infection or gangrene (Apelqvist and Larsson, 2000). In people with healed diabetic foot ulcers, the 5 year cumulative rate of ulcer recurrence is $66 \%$ and of amputation is $12 \%$ (Apelqvist et al., 1993). The high amputation incidence and healing failure after lower extremity amputation for the treatment of diabetic foot ulcer (Malay et al., 2006) is a distinct signal that the efficiency of conventional medical treatments used is less than optimal. This substantiates the need to search for effective therapeutic alternatives and diminish the suffering and high economic and social costs caused by this common diabetic patient complication. Various medicinal plants have been used traditionally for the treatment of circulatory obstructive diseases. In the last couple of decades many of their active principles and action mechanisms have been discovered. Also, traditional healing know-how has been proven to be effective in many cases. This raised the possibility of using herbal therapeutic protocols to complement conventional treatments for complications in diabetes. Specially, since there was mounting evidence which demonstrated that medicinal plants contained synergistic and/or side-effect neutralizing combinations (Thyagarajan et al., 2007; Gilani and Rahman, 2005). In contrast to synthetic pharmaceuticals based upon single chemicals, phytomedicines exert their beneficial effects through the additive or synergistic action of their multitude of constituents acting at single or multiple target sites (Dalby-Brown et al., 2005); because of their primary and secondary metabolite roles (Greenspan et al., 1994) and the adjuvant substances which enhance the activity of components actually responsible for the effect (Gilbert et al., 2003). In order to take the maximum advantage of the therapeutic properties as well as benefits of the synergistic action of the active principles in medicinal plants, it is necessary to use herbal combinations. Herbal formulations have been used for hundreds of years, however, little was known about the methodology to combine plants and obtain effective compositions. The Systemic Theory provided fundamentals which allowed the formulation of an effective herbal composition for treating diabetic foot (Olalde, 2005; Olalde et al., 2005). The previous section revealed that Circulat's active principles exerted therapeutic effects through a synergistic action, as well as its potential for genetic normalization in diabetic patients (Antoshechkin et al., 2007). 


\subsection{Objective, research design and methods}

The aim was to appraise the clinical efficacy of Circulat in healing diabetic foot, measure the amputation rate and determine patient's tolerance to the treatment. Thus, a retrospective, cohort, study of patients with type 2 diabetes and foot ulcerations from 50 medical centers, from 2004 to 2007. Patients were classified in accordance with The University of Texas Health Science Center Diabetic Wound Classification System (Lavery et al., 1997). Patients were being administered ten Circulat $800 \mathrm{mg}$ capsules twice per day, on an outpatient basis, during a period of two to four months. Each case was followed-up during a period of six months, after the end of the treatment. A patient was considered to attain clinical improvement if the lesion visibly decreased in size and depth, or closure or scarring of the wound was attained. All patients received conventional treatment for metabolism correction, local topic cures and systemic antibiotics. The Inclusion criteria of the study were: Patients of any age and gender diagnosed with Diabetes mellitus type 2, grades D1, D2 and D3 (University of Texas Diabetic Wound classification).

\subsubsection{Results and discussion}

The total number of patients which completed the treatment in accordance with the study's inclusion criteria was 174 . The mean was 61.3 years of age. The gender classification was: 101 male $(58.1 \%)$ and 73 female $(41.9 \%)$. Clinical results are reflected in Table 5 . Amputations were prevented in $88.55 \%$ ( $p<0.00001,99.9999 \%$ ) of all 174 patients in the D1D3 categorization. The treatment was well tolerated; only 4 patients $(2.3 \%)$ had minor gastrointestinal unrest which did not warrant treatment suspension. Conventional diabetic foot treatments, based on: risk factors control, affected area's functional relaxation, metabolism correction, topical cures, antibiotics, rheology improving agents, prostanoid vasoactive therapy, platelet aggregation inhibitors, thrombolytic agents, tricyclic antidepressants or benzodiacepines for neuropathies and invasive treatments, such as endovascular, endarterectomy, by-pass or sympathectomy surgeries, do not manage to prevent small and large amputations which occur in 1.86 to 5.9 per every 1.000 diabetics per year (Bilenko et al, 2006; Winell et al, 2006; Rayman et al, 2004; Lavery et al, 2003; Trautner et al, 2001). Circulat- in combination with conventional therapy- prevented more amputations than various conventional treatments reported (Figure 8).

\begin{tabular}{|l|c|c|c|c|c|}
\hline \multicolumn{1}{|c|}{$\begin{array}{c}\text { University of Texas Diabetic } \\
\text { Wound } \\
\text { classification Grade }\end{array}$} & $\mathbf{N}$ & $\begin{array}{c}\text { Total } \\
\text { scarring }\end{array}$ & $\begin{array}{c}\text { Improvem } \\
\text { ent }\end{array}$ & $\begin{array}{c}\text { Total scarring } \\
+ \\
\text { Improvement }\end{array}$ & $\begin{array}{c}\text { Amputati } \\
\text { on }\end{array}$ \\
\hline $\begin{array}{l}\text { D1: Infected ischemic superficial } \\
\text { wounds, } \\
\text { no tendon, capsule, or bone. }\end{array}$ & 88 & $\begin{array}{c}52 \\
(59.09 \%)\end{array}$ & $\begin{array}{c}36 \\
(40.9 \%)\end{array}$ & $\begin{array}{c}88 / 88 \\
(100 \%)\end{array}$ & - \\
\hline $\begin{array}{l}\text { D2: Infected ischemic wounds, } \\
\text { penetrating to tendon or capsule. }\end{array}$ & 80 & $\begin{array}{c}32 \\
(40 \%)\end{array}$ & $\begin{array}{c}30 \\
(37.5 \%)\end{array}$ & $\begin{array}{c}62 / 80 \\
(77.5 \%)\end{array}$ & $\begin{array}{c}18 / 80 \\
(22.5 \%)\end{array}$ \\
\hline $\begin{array}{l}\text { D3: Infected ischemic wounds, } \\
\text { penetrating to bone or joint. }\end{array}$ & 6 & $\begin{array}{c}4 \\
(66.6 \%)\end{array}$ & - & $\begin{array}{c}4 / 6 \\
(66.6 \%)\end{array}$ & $\begin{array}{c}2 / 6 \\
(33.3 \%)\end{array}$ \\
\hline Total & 174 & $\begin{array}{c}88 \\
(50.57 \%)\end{array}$ & $\begin{array}{c}66 \\
(37.9 \%)\end{array}$ & $\begin{array}{c}154 / 174 \\
(88.5 \%)\end{array}$ & $\begin{array}{c}20 / 174 \\
(11.5 \%)\end{array}$ \\
\hline
\end{tabular}

Table 5. Results of Circulat treatment in Diabetic foot 


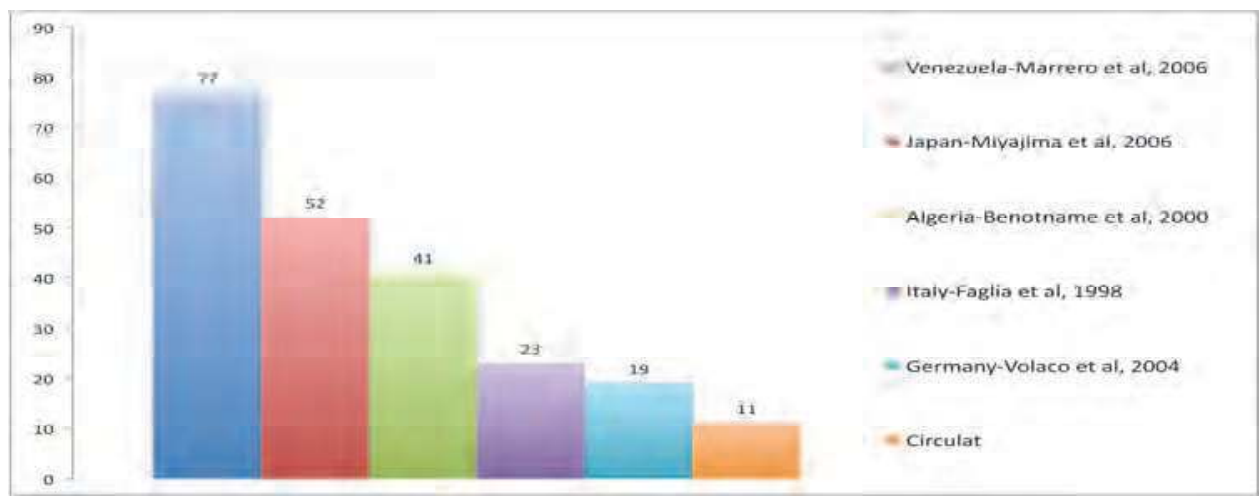

Fig. 8. Examples of Diabetic Foot Amputation rates (\%) in various countries

\section{Formulation's potential in chronic ischemic heart disease treatment}

Context: The previous clinical study (Olalde et al., 2008) demonstrated a significant improvement in 174 diabetic foot patients. These encouraging outcomes and further evidence that other complex herbal formulations could help reduce atherosclerotic endothelium intima thickness (Tripathi et al., 2005) prompted us to evaluate the formulation by measuring the arterial intima-media thickness, a structural marker of early atherosclerosis that relates to the severity and extent of artery disease (Järvisalo et al., 2001), using high-resolution ultrasound (Celermajer et al., 1992). The study (unpublished) showed that treatment with this herbal combination significantly reduced the arterial intima-media thickness. These results further encouraged the formulation of a new hypothesis: could similar results be obtained in the treatment of IHD? If so, is there a potential for CAM complex herbal formulations' intervention in the treatment of Ischemic Heart Disease? Objective: Assess the hypothesis that myocardial perfusion, in chronic ischemic heart disease patients, might safely improve with Circulat. This was evaluated with Gated Single Photon Emission Computerized Tomography (GSPECT) imaging.

\subsection{Introduction}

Ischemic heart disease (IHD) is the leading cause of death -in both genders- worldwide and a major public health problem in the world. WHO (2009) has estimated this to be 7.2 million deaths per year. IHD is the generic designation for a group of pathophysiologically related syndromes resulting from myocardial ischemia (an imbalance between supply -perfusion- and demand for oxygenated blood by the heart). IHD is caused by the atherosclerotic narrowing of one or more coronary arteries and endothelial dysfunction (Thadani, 2004, 2003, 1999). IHD brings oxygen insufficiency and reduces the availability of nutrients as well as the removal of metabolites. For this reason, IHD is generally less well tolerated by the heart than pure hypoxia, such as may be seen in severe anemia, cyanotic heart disease or advanced lung disease. Today much attention is being paid to Chronic Ischemic Heart Disease. This last is increasingly recognized as a dynamic condition. In addition to over acute myocardial infarction, which can precipitate at any time in patients with stable angina pectoris, clinical and sub-clinical ischemic 
events may accumulate and in the long term generate diverse states of chronic cardiac dysfunction. Repetitive episodes of ischemia, whether stress induced or spontaneous, symptomatic or silent, may progressively impair myocardial contractile performance through myocardial stunning or hibernation, and eventually lead to left ventricular remodeling and heart failure. Evidence is accumulating that genetic variability and altered gene and protein expressions contribute to clinical outcomes in ischemic heart disease. Severe ischemic heart disease remains a clinical challenge; many patients have undergone myocardial revascularization procedures due to the extension and diffuseness of the disease. Also, viable options are becoming available for the 'no option' patients with chronic IHD. Instead of revascularization of the highly diseased epicardial coronary arteries, scientists and clinicians are looking -among other- at providing symptomatic relief in these patients via a biological bypass such as a 'master' cardiac stem cell for intracoronary and intra-myocardial injections (Bu et al., 2009). Current treatments include pharmacological agents such as nitrates, aspirin, beta-adrenoceptor antagonists and calcium channel blockers as well as invasive therapies aimed at restoring blood flow, e.g. coronary artery bypass graft (CABG) and improved percutaneous coronary intervention PCI (Tin-Hay et al., 2010). On the other hand, various medicinal plants are being used and researched-for the treatment of coronary heart disease and angina pectoris in China and East Asia, and are referenced in Chinese Materia Medica (Tam et al., 2009; Ling et al., 2008; Duan et al., 2008; Zhao et al., 2007). This last does not preclude quite the contrary it demands, additional pharmacotherapy analysis and herbal medicines drug interaction research (Izzo et al., 2005). Nevertheless, the study and development for synthetic (Yamaguchi et al., 2009; Hirata et al., 2009) and medicinal plant in cardiac treatments continues (Chen et al., 2010; Luo et al., 2009).

\subsubsection{Study materials and methods}

Inclusion Criteria: Patients diagnosed with Chronic Ischemic Cardiopathy. Exclusion Criteria: Acute Coronary Syndrome, severe aortic valve stenosis, arrhythmia with hemodynamic repercussion, acute pericarditis, acute myocarditis, decompensated cardiac insufficiency, acute aortic syndrome, severe anemia, pulmonary embolism, severe arterial hypertension, severe pulmonary arterial hypertension, chronic debilitating diseases, second or third degree atrioventricular block, hypertrophic obstructive cardiomyopathy and valvular cardiomyopathy with hemodynamic compromise. Patients: 20 patients diagnosed with Chronic Ischemic Heart Disease were evaluated. Prior to treatment, tests had determined that 4 of these patients had cardiac ischemia, assessed with cardiac angiography and non invasive methods, and the other 9 patients tested positive for cardiac ischemia with the exercise treadmill testing protocol (Bruce). Initial cardiac ischemia diagnosis was also corroborated by GSPECT control imaging prior to treatment. Patients were receiving treatment with aspirin, $\beta$-blockers, statins, nitrates, clopidogrel and anti-hypertensive medication (diuretics, ACE inhibitors, angiotensin II receptor antagonists, calcium channel blockers). Patients were given a complete physical examination at screening, each month and at the end of the treatment (sixth month). The patients' baseline factors, relevant cardiac conditions and ongoing treatments were established in Table 6. The most pervasive baseline condition risk, evidenced from patients' clinical history (Table 6) was Hypercholesterolemia (14/20; 70\%). On the other hand, the most common treatment was aspirin $(17 / 20 ; 85 \%)$. 


\begin{tabular}{|c|c|c|c|c|c|c|c|c|c|c|c|c|c|c|c|c|c|c|c|c|}
\hline \multirow{3}{*}{ Description } & \multicolumn{20}{|c|}{ Patient Number } \\
\hline & 1 & 0 & 0 & 4 & 5 & 6 & 7 & 0 & 0 & 1 & 1 & 1 & 1 & 1 & 1 & 1 & 1 & 1 & 1 & 2 \\
\hline & 1 & 2 & 3 & 4 & 3 & 0 & $\gamma$ & 0 & 9 & 0 & 1 & 2 & 3 & 4 & 5 & 6 & 7 & 8 & 9 & 0 \\
\hline Gender & M & $\mathrm{F}$ & $\mathrm{M}$ & $\mathrm{M}$ & $\mathrm{M}$ & $\mathrm{M}$ & $\mathrm{M}$ & F & $\mathrm{M}$ & $\mathrm{F}$ & $\mathrm{F}$ & $\mathrm{F}$ & $\mathrm{M}$ & $\mathrm{M}$ & $\mathrm{F}$ & M & $\mathrm{F}$ & $\mathrm{M}$ & M & $\mathrm{M}$ \\
\hline \multirow{2}{*}{ Age } & \multirow{2}{*}{68} & 7 & 6 & 6 & 6 & 4 & 6 & 5 & 5 & 7 & 7 & 5 & 5 & 4 & 6 & 8 & 6 & 5 & 5 & 6 \\
\hline & & 8 & 9 & 4 & 7 & 1 & 1 & 7 & 9 & 3 & 5 & 3 & 8 & 8 & 6 & 0 & 7 & 7 & 9 & 8 \\
\hline $\begin{array}{l}\text { Myocardial } \\
\text { infarction }\end{array}$ & $\mathrm{N}$ & Y & $\mathrm{N}$ & Y & $\mathrm{N}$ & $\mathrm{N}$ & $\mathrm{N}$ & $\mathrm{N}$ & Y & $\mathrm{Y}$ & $\mathrm{N}$ & $\mathrm{N}$ & $\mathrm{N}$ & $\mathrm{N}$ & Y & Y & Y & Y & $\mathrm{Y}$ & $\mathrm{Y}$ \\
\hline CABG & $\mathrm{N}$ & $\mathrm{N}$ & $\mathrm{N}$ & $\mathrm{N}$ & $\mathrm{N}$ & $\mathrm{N}$ & $\mathrm{N}$ & $\mathrm{N}$ & $\mathrm{N}$ & $\mathrm{N}$ & $\mathrm{N}$ & $\mathrm{N}$ & $\mathrm{N}$ & $\mathrm{N}$ & $\mathrm{N}$ & Y & $\mathrm{N}$ & $\mathrm{N}$ & $\mathrm{N}$ & $\mathrm{N}$ \\
\hline PCI & $\mathrm{N}$ & $\mathrm{N}$ & $\mathrm{N}$ & $\mathrm{N}$ & $\mathrm{N}$ & $\mathrm{N}$ & Y & $\mathrm{N}$ & $\mathrm{N}$ & $\mathrm{N}$ & $\mathrm{N}$ & $\mathrm{N}$ & $\mathrm{N}$ & $\mathrm{N}$ & $\mathrm{N}$ & $\mathrm{N}$ & $\mathrm{N}$ & $\mathrm{N}$ & $\mathrm{N}$ & $\mathrm{N}$ \\
\hline Diabetes & $\mathrm{N}$ & $\mathrm{N}$ & $\mathrm{N}$ & $\mathrm{N}$ & $\mathrm{N}$ & $\mathrm{Y}$ & $\mathrm{N}$ & $\mathrm{N}$ & $\mathrm{N}$ & $\mathrm{N}$ & $\mathrm{N}$ & $\mathrm{N}$ & $\mathrm{N}$ & $\mathrm{N}$ & $\mathrm{N}$ & Y & $\mathrm{N}$ & $\mathrm{N}$ & $\mathrm{N}$ & $\mathrm{Y}$ \\
\hline $\begin{array}{c}\text { Former } \\
\text { smoker } \geq 30 \mathrm{~d}\end{array}$ & $\mathrm{~N}$ & $\mathrm{~N}$ & $\mathrm{~N}$ & $\mathrm{~N}$ & $\mathrm{~N}$ & $\mathrm{~N}$ & $\mathrm{~N}$ & $\mathrm{~N}$ & Y & $\mathrm{N}$ & $\mathrm{N}$ & $\mathrm{N}$ & $\mathrm{Y}$ & $\mathrm{N}$ & $\mathrm{Y}$ & $\mathrm{N}$ & $\mathrm{N}$ & $\mathrm{N}$ & $\mathrm{Y}$ & $\mathrm{Y}$ \\
\hline Hypertension & $\mathrm{N}$ & Y & $\mathrm{Y}$ & Y & $\mathrm{N}$ & $\mathrm{N}$ & $\mathrm{Y}$ & $\mathrm{N}$ & Y & $\mathrm{Y}$ & $\mathrm{N}$ & $\mathrm{N}$ & $\mathrm{N}$ & $\mathrm{N}$ & $\mathrm{Y}$ & Y & $\mathrm{Y}$ & $\mathrm{N}$ & $\mathrm{N}$ & $\mathrm{Y}$ \\
\hline $\begin{array}{l}\text { Hypercholest- } \\
\text { erolemia }\end{array}$ & $\mathrm{Y}$ & Y & $\mathrm{N}$ & $\mathrm{N}$ & $\mathrm{Y}$ & Y & $\mathrm{N}$ & Y & $\mathrm{N}$ & Y & $\mathrm{N}$ & $\mathrm{N}$ & $\mathrm{Y}$ & Y & Y & $\mathrm{Y}$ & $\mathrm{Y}$ & Y & $\mathrm{Y}$ & $\mathrm{Y}$ \\
\hline BAA & $\mathrm{N}$ & $\mathrm{N}$ & $\mathrm{N}$ & $\mathrm{N}$ & Y & $\mathrm{Y}$ & $\mathrm{N}$ & Y & Y & $\mathrm{N}$ & Y & $\mathrm{N}$ & $\mathrm{N}$ & $\mathrm{N}$ & Y & $\mathrm{N}$ & Y & $\mathrm{N}$ & $\mathrm{N}$ & $\mathrm{Y}$ \\
\hline Statins & $\mathrm{N}$ & $\mathrm{N}$ & Y & Y & $\mathrm{N}$ & $\mathrm{N}$ & $\mathrm{Y}$ & $\mathrm{N}$ & $\mathrm{N}$ & Y & $\mathrm{N}$ & $\mathrm{N}$ & $\mathrm{N}$ & $\mathrm{Y}$ & Y & Y & $Y$ & Y & $\mathrm{Y}$ & $\mathrm{Y}$ \\
\hline Aspirin & Y & $\mathrm{N}$ & Y & $\mathrm{N}$ & $\mathrm{Y}$ & $\mathrm{N}$ & $\mathrm{Y}$ & Y & Y & Y & Y & Y & Y & Y & Y & Y & Y & Y & $\mathrm{Y}$ & $\mathrm{Y}$ \\
\hline $\begin{array}{l}\text { Oral Anti- } \\
\text { diabetics }\end{array}$ & $\mathrm{N}$ & $\mathrm{N}$ & $\mathrm{N}$ & $\mathrm{N}$ & $\mathrm{N}$ & $\mathrm{Y}$ & $\mathrm{N}$ & $\mathrm{N}$ & $\mathrm{N}$ & $\mathrm{N}$ & $\mathrm{N}$ & $\mathrm{N}$ & $\mathrm{N}$ & $\mathrm{N}$ & $\mathrm{N}$ & Y & $\mathrm{N}$ & $\mathrm{N}$ & $\mathrm{N}$ & $\mathrm{Y}$ \\
\hline ACEI or ARB & $\mathrm{N}$ & $\mathrm{N}$ & Y & $\mathrm{N}$ & $\mathrm{N}$ & $\mathrm{Y}$ & $\mathrm{N}$ & $\mathrm{N}$ & Y & $\mathrm{N}$ & Y & $\mathrm{N}$ & $\mathrm{N}$ & $\mathrm{N}$ & Y & Y & Y & $\mathrm{N}$ & $\mathrm{N}$ & $\mathrm{Y}$ \\
\hline $\begin{array}{l}\mathrm{Ca}^{2+}-\text { channel } \\
\text { antagonist }\end{array}$ & $\mathrm{N}$ & $\mathrm{N}$ & $\mathrm{N}$ & $\mathrm{N}$ & $\mathrm{N}$ & $\mathrm{N}$ & $\mathrm{N}$ & $\mathrm{N}$ & $\mathrm{N}$ & $\mathrm{N}$ & $\mathrm{N}$ & $\mathrm{N}$ & $\mathrm{N}$ & $\mathrm{N}$ & $\mathrm{N}$ & $\mathrm{N}$ & $\mathrm{N}$ & $\mathrm{N}$ & $\mathrm{N}$ & $\mathrm{N}$ \\
\hline Diuretics & $\mathrm{N}$ & $\mathrm{N}$ & $\mathrm{N}$ & $\mathrm{N}$ & $\mathrm{N}$ & $\mathrm{Y}$ & $\mathrm{N}$ & $\mathrm{N}$ & Y & $\mathrm{N}$ & $\mathrm{Y}$ & $\mathrm{N}$ & $\mathrm{N}$ & $\mathrm{N}$ & $\mathrm{Y}$ & $\mathrm{Y}$ & Y & $\mathrm{N}$ & $\mathrm{N}$ & $\mathrm{Y}$ \\
\hline $\begin{array}{l}\text { Legends. A } \\
\text { Receptor Bl } \\
\text { Bypass Graf } \\
\text { Intervention } \\
\text { Y: Yes. All d }\end{array}$ & & & F & ma & le: & $\mathbf{M}$ & le: & M; & N: & Jo; & PCI: & Per & cut & aneo & & & & & & \\
\hline
\end{tabular}

Table 6. Patients' Baseline Characteristics

Patients were instructed to receive ten $800 \mathrm{mg}$ capsules b.i.d., of the herbal composition. Assessment of cardiac functions: The Bruce test, named after Dr. Robert A. Bruce, involves walking on a slanted treadmill while patient's time resistance is measured and the heart is monitored by an electrocardiograph. Patients' Pre -and Post- treatment, treadmill resistance time (Functional Capacity Time or FCT) were determined and reflected in Figure 9. 


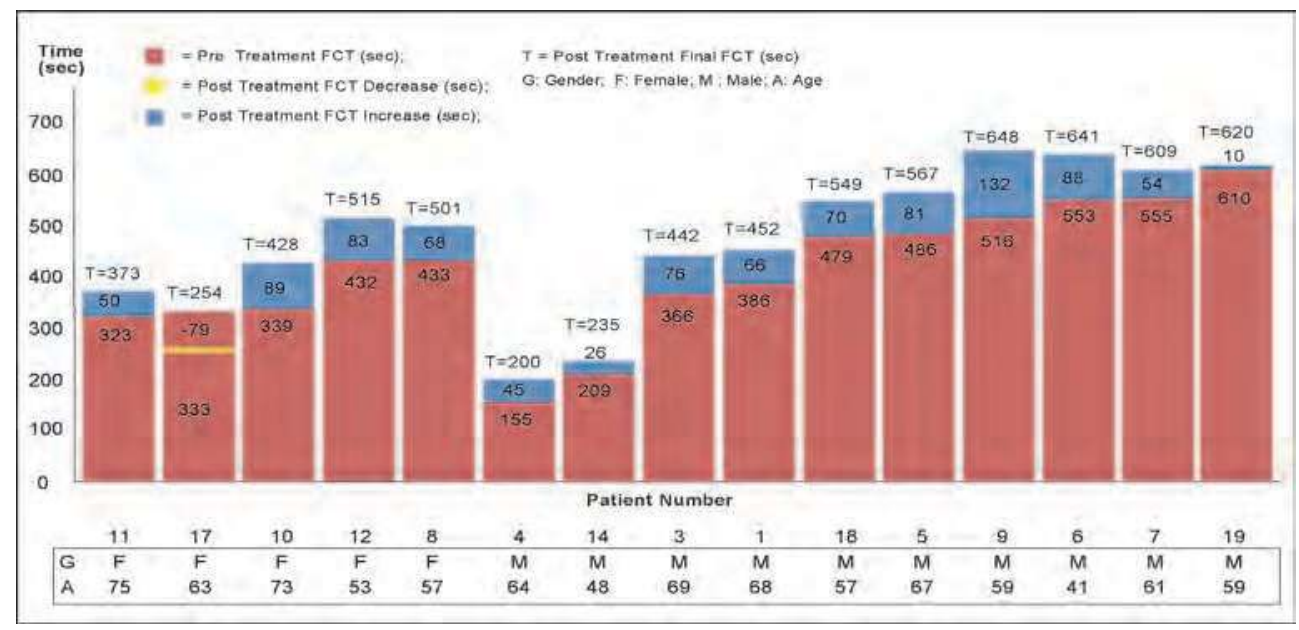

Note: Patients 2, 13, 15, 16 and 20 were unable to carry out the test due to physical limitations.

Fig. 9. Pre and Post (After) Treatment Functional Capacity Time per patient

\subsection{Assessment of regional myocardial perfusion defect}

Patient's -before and after Circulat treatment- post-effort -left ventricle- myocardial perfusion defect percentages were assessed by GSPECT imaging with technetium 99mtetrofosmin injection. This technique uses imaging procedures for detection with the help of gamma rays. In the procedure, the radioisotope is used on the patient and the gamma ray emitted by the technetium 99 that is in the radioisotope is captured on a special gamma camera. The total scanning time for the heart of a patient takes around twenty minutes which is enough time given the half life span of technetium 99. This isotope has a short half life -about six hours- and this small longevity is very useful for medical purposes. Recollection of data [imaging] is quick and the amount of radiation which a patient undergoes through is very low in intensity. GSPECT myocardial perfusion imaging is a widely used nuclear imaging procedure for diagnosis and management of coronary artery disease -which is the most common cause of heart failure. It is extensively available with superb standardization and reproducibility (Chen et al., 2008). For this study, the Phillips Forte (2007 model) AZ Spect Dual Headed Camera with an AUTOQUANT -quantitative algorithm- program for image processing was used. A 20 segment analysis was performed. Results of Perfusion Defect evolution are reflected in Figure 10.

\subsubsection{Results}

Clinical: Patients' Pre and Post Treatment Functional Capacity Time (treadmill evaluation) comparison (Figure 9) revealed that all patients who were physically capable to carry test out -except patient 17- improved their timed resistance [Female Improvement Median $=42.2$ sec; Male Improvement Median $=64.8 \mathrm{sec}$. Finally, patients' Post-Effort Left Ventricle Perfusion Defect imaging percentage values (Figure 10) were compared before and after six months treatment. Of the study group, 15 patients [75\%] improved their perfusion defect. Statistics: The significance of the results was determined with the Wilcoxon Matched-Pairs Signed-Ranks Test ( $\leq 6.104$ e-05; \%=99.9999). All statistical data was determined using 
SPSS 17.0 for Windows. Adverse events: No patients suffered any adverse events during the treatment.

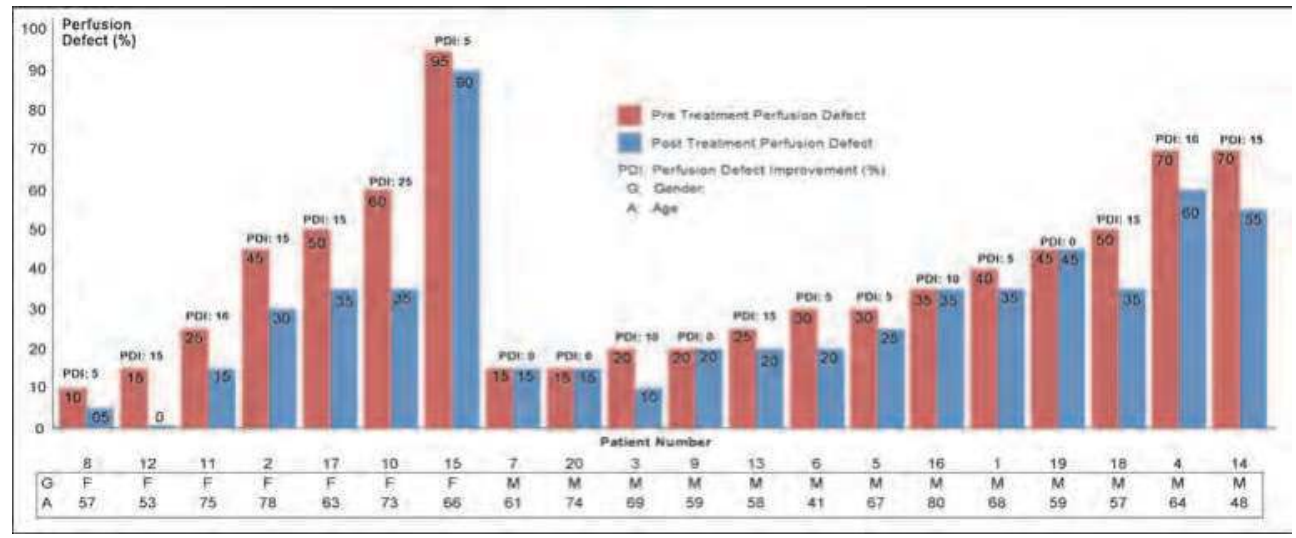

Fig. 10. Patient Cardiac Perfusion Defect Evolution (Ranked by age and gender)

\subsection{Discussion on ischemic heart treatment}

The results answered the formulated [raised] hypothesis. Indeed, CAM -and Circulat- can have a role in the treatment of Ischemic Chronic Heart Disease. This is supported by the number of patients (15 out of 20 ) which quantitatively improved their left ventricular perfusion capacity. Effects of this treatment are thought to be caused, among others, by vascular endothelium structure and function improvement, angiogenesis and tissue perfusion enhancement. Also to be noticed is patients' disease evolution according to initial perfusion defect -reflected in Figure 10. There seems to be a correlation suggesting that initial stages of ischemia development -corresponding to lower Pre-Treatment perfusion defect- are more precociously responsive to a short (6 month) treatment, thus advocating use of the formulation as a preventive remedy against chronic ischemic heart disease. However, to measure the treatment's potential effectiveness, in patients with acute perfusion defect, a longer lasting treatment -of at least one year is necessary. Just as pathologies -with critical conditions- warrant longer management periods.

\section{Conclusions on chapter}

A theory is as good as the praxis that backs it up. On one hand the gene expression study (Antoscheckin et al, 2007) established that a complex herbal formulation, designed in accordance with Systemic Theory precepts, had synergistic properties as well as the capacity to modulate genes implicated in diabetes development, energy metabolism, protein synthesis, glucose metabolism and signaling pathways. It also demonstarted that four genes (IL6, HMGA1, SLC19A2 and C4A) involved in the development and progression of diabetes are strongly regulated by Circulat. These bio-molecular results were confirmed with the further evaluation of diabetic foot management (Olalde et al., 2008) which provided clinical substantiation that a complex herbal formulation could be successful in providing therapeutic response to such a circulatory chronic disease. However, the result obtained in the reduction of perfusion defect in Chronic Ischemic patients was unexpected. It also 
requires further validation. The authors are prolonging the length of the treatment -and the study- to one year. From this distance a better image of its potential therapeutic use can be assessed. However, there is room for cautious optimism. Evidence is accumulating that genetic variability and altered gene and protein expressions contribute to clinical outcomes in ischemic heart disease. It is likely therefore, that expression-profiling-based approaches to chronic degenerative diseases such as diabetes and ischemic heart disease with herbal medicines will become standard in phytopharmacology in the very near future. Resuming: a)The confirmation of Circulat's synergistic synergistic gene modulating capabilities (in 32 genes, among which are four significant genes related to diabetes; b) The clinical outcomes of diabetic foot management which prevented the amputation of $88.5 \%$ of the study's total population ; and c) The good response to therapy in $75 \%$ of the patients ( $\mathrm{p} \leq 6.104 \mathrm{e}-05 ; \%=$ 99.9999) by the composition in a GSPECT evaluated limited Phase II Chronic Ischemic Heart Disease suggest that treatment of circulatory pathologies with substances which act only on function and structure might be an incomplete approach. Whether the findings in circulatory chronic disease studies -and their results- can be generalized in confirming the systemic approach (E, I and $\mathrm{O}$ ) is something that should be continued in medicinal science. Since this may pave the way for a new integral vision of therapeutics in general having started to proove its validity in circulatory chronic diseases in particular.

\section{Acknowledgement}

The authors wish to thank Dr. Edwin L. Cooper for his trust and invaluable guidance. Few can vouch such a supportive professor. Also, our appreciation to En Jose Olalde whose vision prompted a new therapeutic approach to chronic degenerative diseases recognizing that '...the essence of science...' is to have the valour to '... ask an impertinent question...' and get us on the road '...to a pertinent answer...' (Jacob Bronowski). Last but not least to Daniel Tucci, who although does not appear as an author provided figures and graphs, the art, that rounds up the science we all are so passionate about.

\section{References}

Abbott, CA.; Carrington, AL. \& Ashe, H. (2002). The North-West Diabetes Foot Care Study: incidence of, and risk factors for new diabetic foot ulceration in a community-based patient cohort. Diabet Med Vol.19,No.5(2002),pp.377-84,ISSN 1464-5491

Abidov, M.; Crendal, F.; Grachev, S.; Seifulla, R. \& Ziegenfuss, T. (2003). Effect of extracts from Rhodiola rosea and Rhodiola crenulata (Crassulaceae) roots on ATP content in mitochondria of skeletal muscles. Bull Exp Biol Med Vol.136, No.6 (2003) PP. 585-7, ISSN 1573-8221

Acharya, SK.; Dasarathy, S.; Tandon, A.; Joshi, YK. \& Tandon BN.(1993). A preliminary open trial on interferon stimulator (SNMC) derived from Glycyrrhiza glabra in the treatment of subacute hepatic failure. Indian J Med Res Vol. 98,(1993), pp.69-74, ISSN: 0019-5359

Adams, JD. \& Garcia C. (2005). The adavantages of traditional Chumash healing. Evid Based Complement Alternat Med; Vol.2, No.1 (June 2005), pp.19-23, ISSN 1741-427X

Agrawal, P.; Rai, V. \& Singh, RB.(1996). Randomized placebo-controlled, single blind trial of holy basil leaves in patients with noninsulin-dependent diabetes mellitus. Int J Clin Pharmacol Ther Vol.34,No.9 (1996); pp.406-9,ISSN 0174-4879 
Akesson, C.; Lindgren, H. \& Pero, RW. (2003) An extract of Uncaria tomentosa inhibiting cell division and NF-kappa B activity without inducing cell death. Int Immunopharmacol Vol.3,No.13-14 (Dec 2003), pp.1889-900, ISSN 0074-0276

Albrecht-Buehler G. 1998. Altered drug resistance of microtubules in cells exposed to infrared light pulses: are microtubules the 'nerves' of cells? Cell Motil Cytoskel Vol.40, No.2 (Dec 1998), pp.183-92. ISSN (electronic): 1097-0169.

Albrecht Buehler, G. (1985) Is cytoplasm intelligent too?, In:Cell Muscle Motility, J.W. Shay, (Ed.), 1-21, Plenum Press, ISBN 906450 5020, New York-London

Antoshechkin, A. (2001). The Primary Adaptogens. Ceptoma Publishing Co., Clearwater, USA

Antoshechkin, A.; Olalde, J.; Magarici, M.; Muhammad, A.; Salom, A.; Suarez, J. \& Amendola, F. (2007). Analysis of effects of the herbal preparation Circulat on gene expression levels in cultured human fibroblasts. Phytotherapy Research Vol.21,No.6,(August, 2007), pp. 777-789,ISSN 1099-1573

Apelqvist, J.; Larsson, J. \& Agardh, CD. (1993). Long-term prognosis for diabetic patients with foot ulcers. J Intern Med Vol. 233, No.6,(1993) pp.485-491,ISSN 1939-1676

Apelqvist, J. \& Larsson, J. (2000). What is the most effective way to reduce incidence of amputation in the diabetic foot? Diabetes Metab Res Rev Vol.16,Suppl 1,(Oct 2000),pp.S75-83, ISSN 1520-7560.

Armstrong, DG.; Lavery, LA.; Quebedeaux, TL. \& Walker, SC. (1997). Surgical morbidity and the risk of amputation due to infected puncture wounds in diabetic versus nondiabetic adults. South Med J 90:384-9, ISSN 1541-8243

Ashburner, M., Ball, CA.; Blake, JA.; Botstein, D.; Butler, H.; Cherry, JM. \& Davis, AP. (2000). The Gene Ontology Consortium. Gene Ontology tool for the unification of Biology. Nature Genet Vol.25 (2000),pp.25-29, ISSN 1061-4036

Bae, JW. \& Lee, MH. (2004). Effect and putative mechanism of action of ginseng on the formation of glycated hemoglobin in vitro. J Ethnopharmacol Vol.91,No.1,(Mar 2004),pp.137-40, ISSN 1539-3704

Baggio, E.; Gandini, R.; Plancher, AC.; Passeri, M. \& Carmosino, G. (1994) Italian multicenter study on the safety and efficacy of coenzyme Q10 as adjunctive therapy in heart failure. CoQ10 Drug Surveillance Investigators. Mol Aspects Med Vol.15,Suppl.1(1994),pp.S287-94,ISSN 1872-9452

Bence, AK. \& Crooks, PA. (2003).The mechanism of l-canavanine cytotoxicity: arginy 1tRNA synthetase as a novel target for anticancer drug discovery. J Enzyme Inhib Med Chem Vol.18,No.5,(2003),pp.383-94,ISSN 1475-6374

Benotmane, A.; Mohammedi, F. \& Ayad, F. (2000). Diabetic foot lesions: etiologic and prognostic factors. Diabetes Metab Vol. 26,No. 2,(April 2000),pp.113-7,ISSN 15207560

Bhattacharya, SK. \& Muruganandam, AV. (2003). Adaptogenic activity of Withania somnifera: an experimental study using a rat model of chronic stress. Pharmacol Biochem Behav Vol. 75,No.3,(Jun 2003),pp.547-55,ISSN 0091-3057

Bilenko, V.; Bilenko, N.; Harman-Boehm, I.; Atar, D.; Rosen, S. \& Weitzman, S. (2006). [Trends and characteristics of diabetes-related lower limb amputations in the Negev, 1996-1999] Harefuah Vol.145,No.10,pp.709-12 
Blalock, JE. (1989). A molecular basis for bidirectional communication between the immune and neuroendocrine systems. Physiol Rev Vol.69,No.1,(Jan 1989),pp.1-32,ISSN 15221210.

Blumenthal, M.; Busse, WR.; Goldberg,A. \& Gruenwald, J. (ed(s)). (1998). The Complete German Commission E Monographs., 1998,ISBN 0-96555-550-X,American Botanical Council, Austin, USA

Bocharova, OA.; Lyzhenkova, MA.; Mezentseva, MV.; Semernina, VV. \& Knyazhev, VA. (2003). Phytoadaptogen for preventive oncology: immune biological criteria of composition. Bull Exp Biol Med Vol.136,No. 6,(Dec 2003),pp.591-4,ISSN 1573-8221

Borchers, AT.; Stern, JS.; Hackman, RM.; Keen, CL. \& Gershwin, ME. (1999). Mushrooms, tumors, and immunity. Proc Soc Exp Biol Med Vol.221,No.4,(Sept 1999),pp.281-93, ISSN 0037-9727

Bouaziz, N.; Michiels, C. \& Janssens, D. (1999). Effects of Ruscus extract and hesperidin methylchalcone on hypoxia-induced activation of endothelial cells. Int Angiol Vol.18,No.4,(Dec 1999),pp. 306-12, ISSN 0392-9590

Brekhman, II. \& Dardymov, IV. (1969). New Substances of plant origin which increase nonspecific resistance. Annu Rev Pharmacol Vol.9,(1969),pp.419-30, ISSN 0362-1642

Brown, AC.; Hairfield, M.; Richards, DG.; McMillin, DL.; Mein, EA. \& Nelson, CD. (2009). Medical nutrition therapy as a potential complementary treatment for psoriasis-five case reports. Altern Med Rev Vol.9,No.3,(Sep 2004),pp. 297-307, ISSN 1089-5159

Bu, L.; Jiang, X.; Martin-Puig, S.; Caron, L.; Zhu, S.; Shao, Y.; Roberts, DJ.; Huang, PL.; Domian, IJ. \& Chien, KR.(2009). Human ISL1 heart progenitors generate diverse multipotent cardiovascular cell lineages. Nature Vol. 460, No.7251, (July 2009), pp.113-117, ISSN 1476-4687

Bucci, LR. (2000). Selected herbals and human exercise performance. Am J ClinNutr Vol.72, S.2,(Aug 2000), pp.624S-36,ISSN 1938-3207

Calle, J.; Toscano, M.; Pinzon, R.; Baquero, J. \& Bautista, E. (1999) Antinociceptive and uterine relaxant activities of Viburnum toronis alive (Caprifoliaceae). J Ethnopharmacol Vol.66,No.1,(July 1999),pp.71-3, ISSN 1539-3704

Carrero, JJ.; Lopez-Huertas, E.; Salmeron, LM.; Baro, L. \& Ros, E. (2005). Daily supplementation with (n-3) PUFAs, oleic acid, folic acid, and vitamins B-6 and E increases pain-free walking distance and improves risk factors in men with peripheral vascular disease. J Nutr Vol.135,No. 6,(June 2005),pp.1393-9, ISSN 15416100 .

Cavagnaro, J. \& Lewis, RM. (1989). Bidirectional regulatory circuit between the immune and neuroendocrine systems. Year Immunol Vol.4,(1989),pp.241-52,ISSN 0256-2308

Ccahuana-Vasquez, RA.; Santos, SS.; Koga-Ito, CY. \& Jorge, AO. (2007). Antimicrobial activity of Uncaria tomentosa against oral human pathogens. Pesqui Odontol Bras Vol.21,No.1,(Jan-Mar 2007), pp.46-50, ISSN 1517-7491

Celermajer, DS.; Sorensen, KE.; Gooch, VM.; Spiegelhalter, DJ.; Miller, OI.; Sullivan, ID.; Lloyd, JK. Deanfield, JE. (1992) Non-invasive detection of endothelial dysfunction in children and adults at risk of atherosclerosis. Lancet Vol.340, No.8828,(Nov 1992),pp.1111-1115, ISSN ONLI-2296

Chadwick, WA.; Roux, S.; van de Venter, M.; Louw, J. \& Oelofsen, W. (2007). Anti-diabetic effects of Sutherlandia frutescens in Wistar rats fed a diabetogenic diet. J Ethnopharmacol Vol.109,No.1,(July 2006),pp.121-7, ISSN 1539-3704 
Chainani-Wu N. (2003) Safety and anti-inflammatory activity of curcumin: a component of tumeric (Curcuma longa). J Altern Complement Med Vol.9,No.1,(Feb 2003), pp.1618,ISSN 1557-7708

Chen, H.; Peng, P.; Cheng, L.; Lin, X.; Chung, S. \& Li, M. (2010). Reconstitution of coronary vasculature in ischemic hearts by plant-derived angiogenic compounds. Int $J$ Cardiol (Epub Dec 2010) ISSN: 0167-5273

Chen, J.; Bax, J.; Henneman, M.; Boogers, MJ. \& Garcia, EV. (2008). Is nuclear imaging a viable technique to assess dyssynchrony? Eurospace Vol.10, S.iii,(Nov 2008), pp.101105, ISSN 1532-2092

Chen, ZP.; Cai, Y \& Phillipson, JD. (1994). Studies on the anti-tumour, anti-bacterial and wound-healing properties of dragon's blood. Planta Med Vol.60,No.6(1994),pp.5415,ISSN 1439-0221

Chen, C.; Shum, Y.; \& Yang, S. (2004). The modernization of traditional Chinese medicine in Taiwan -past, present and future. In: Complementary and Alternative Approaches to Biomedicine, E. L. Cooper,N. Yamaguchi, (Ed(s)), 167-79, Kluwer Academic/Plenum Publishers, ISBN 978-030-6482-88-5, New York, USA

Cheng, Z.; Pang, T.; Gu, M.; Gao, AH.; Xie, CM.; Li, JY.; Nan, FJ. \& Li, J. (2006). Berberinestimulated glucose uptake in L6 myotubes involves both AMPK and p38 MAPK. Biochim Biophys Acta Vol. 1760, No.11 (Nov 2006), pp.1682-9, ISSN 0006-3002

Chrubasik, S.; Kunzel, O.; Model, A.; Conradt, C. \& Black, A. (2001). Treatment of low back pain with a herbal or synthetic anti-rheumatic: a randomized controlled study. Willow bark extract for low back pain. Rheumatology (Oxford) Vol. 40,No.12,(Dec 2001), pp.1388-93, ISSN 1462-0332

Chrubasik, S.; Model, A.; Black, A. \& Pollack, S. (2003). A randomized double blind pilot study comparing Doloteffin and Vioxx in the treatment of lower back pain. Rheumatology (Oxford) Vol.42, No. 1, (Jan 2003), pp.141-8, ISSN 1462-0332

Chrungoo, VJ.; Singh, K. \& Singh, J. (1997). Silymarin mediated differential modulation of toxicity induced by carbontetrachloride, paracetamol and d-galactosamine in freshly isolated rat hepatocytes. Indian J ExpBiol Vol.35 No.6, (Jun 1997), pp.611-7, ISSN 0975-1009

Cooper, EL. (2004). Commentary on CAM and NK cells by Kazuyoshi Takeda and Ko Okumura. Evid Based Complement Alternat Med Vol.1,No.1,(Jun 2004), pp. 29-34, ISSN 1741-4288

Cundell, DR.; Matrone, MA.; Ratajczak, P. \& Pierce, JDJr. (2003). The effect of aerial parts of Echinacea on the circulating white cell levels and selected immune functions of the aging male Sprague-Dawley rat. Int Immunopharmacol Vol.3, No.7, (Jul 2003), pp.1041-8, ISSN 0074-0276

Dalby-Brown, L.; Barsett, H.; Landbo, AK.; Meyer, AS. \& Mølgaard, P. (2005). Synergistic antioxidative effects ofalkamides, caffeic acid derivatives, and polysaccharide fractions from Echinacea purpurea on in vitro oxidation of human low-density lipoproteins. Agric Food Chem Vol.53, No.24 (Nov 2005), pp. 9413-23, ISSN 16845315

Davydov, M. \& Krikorian, AD. (2000). Eleutherococcus senticosus (Rupr. \& Maxim.) Maxim. (Araliaceae) as an adaptogen: a closer look. J Ethnopharmacol Vol.72, No.3, (Oct 2000), pp.345-93, ISSN 1539-3704 
Dhuley, JN. (2000). Adaptogenic and cardioprotective action of ashwagandha in rats and frogs. J Ethnopharmacol Vol.70, No.1 (April 2000), pp.57-63, ISSN: 1539-3704

Dietz, BM.; Mahady, GB,.; Pauli, GF. \& Farnsworth, NR. (2005). Valerian extracts and valerenic acid are partial agonists of the 5-HT5a receptor in vitro. Brain Res Mol Brain Res Vol.138, No.2,(August 2005), pp.191-7, ISSN 0169-328X

Duan, X.; Zhou L, Wu.; T, Liu, G.; Qiao, J.; Wei, J.; Ni, J.; Zheng, J.; Chen, X \& Wang, Q. (2008). Chinese herbal medicine suxiao jiuxin wan for angina pectoris. Cochrane Database Syst Rev (Jan 2008) CD004473, ISSN 1469-493X

Faglia, E.; Favales, F.; Aldeghi, A.; Calia, P.; Quarantiello, A.; Barbano, P.; Puttini, M.; Palmieri, B.; Brambilla, G.; Rampoldi, A.; Mazzola, E.; Valenti, L.; Fattori, G.; Rega, V.; Cristalli, A.; Oriani, G.; Michael, M. \& Morabito, A. (1998). Change in major amputation rate in a center dedicated to diabetic foot care during the 1980s: prognostic determinants for major amputation. J Diabetes Complications Vol. 12, No.2,(March-April 1998), pp.96-102, ISSN 1935-5548

Farnsworth, NR.; Kinghorn, AD.; Soejarto, DD. Waller, DP. (1985). Siberian ginseng (Eleutherococcus senticosus): current status as an adaptogen. In: Economic and Medicinal Plant Research, Vol.1, H. Wagner, H. Hikino, NR. Farnsworth, (Ed(s)), 217-284, Academic Press, London, UK,

Feng, CG.; Zhang, LX. \& Liu, X. (2005). [Progress in research of aldose reductase inhibitors in traditional medicinal herbs]. Zhongguo Zhong Yao Za Zhi Vol.30, No.19, (Oct 2005), pp.1496-500, ISSN: 1001-5302

Fernando, DJ. (1996). The prevalence of neuropathic foot ulceration in Sri Lankan diabetic patients. Ceylon Med J Vol.41, No.3, (Sept 1996), pp.96-8, ISSN 0009-0875

Foti, D.; Chiefari, E.; Fedele, M.; Iuliano, R.; Brunetti, L.; Paonessa, F.; Manfioletti, G.; Barbetti, F.; Brunetti, A.; Croce, CM.; Fusco, A. \& Brunetti, A. (2005). Lack of Architectural factor HMGA1 causes insulin resistance and diabetes in humans and mice. Nat Med Vol.11, No.7,(May 2005),pp.765-773, ISSN 1078-8956

Franz, G. (1993). The senna drug and its chemistry. Pharmacology Vol.47, S.1, (Oct 1993), pp. S2-6, ISSN 0031-7012

Freeman, MR. \& Solomon, KR. (2004). Cholesterol and prostate cancer. J Cell Biochem Vol.91, No.1, pp.54-69,ISSN 1460-2105

Freier, DO.; Wright, K.; Klein, K. \& Voll, D. (2003). Enhancement of the humoral immune response byEchinacea purpurea in female Swiss mice. Immunopharmacol Immunotoxicol Vol.25, No.4,(Nov 2003), pp.551-60, ISSN 1532-2513

Gaffney, BT.; Hugel, HM. \& Rich, PA. (2001). Panax ginseng and Eleutherococcus senticosus may exaggerate an already existing biphasic response to stress via inhibition of enzymes which limit the binding of stress hormones to their receptors. Med Hypotheses Vol.56,No.5,(May 2001), pp.567-72, ISSN 0306-9877

Geng, XX.; Yang, Q.; Xie, RJ.; Luo, XH.; Han, B.; Ma, L.; Li, CX \& Cheng, ML.(2005). In vivo effects of Chinese herbal recipe, Danshaohuaxian, on apoptosis and proliferation of hepatic stellate cells in hepatic fibrotic rats. World J Gastroenterol Vol.11,No.4,(Jan 2005),pp.561-6,ISSN 1007-9327

Gilani, AH. \& Rahman, AU. (2005). Trends in ethnopharmocology. J Ethnopharmacol Vol.100,No. 1-2,(Jan 2005), pp.43-49, ISSN 1539-3704

Gilbert, B. \& Alves, LF. (2003). Synergy in plant medicines. Curr Med Chem Vol.10, No.1, (Jan 2003), pp.13-20, ISSN 1568-0266 
Goldmann, WH.; Sharma, AL.;Currier, SJ.; Johnston, PD.; Rana, A. \& Sharma, CP.(2001). Saw palmetto berry extract inhibits cell growth and Cox-2 expression in prostatic cancer cells. Cell Biol Int Vol.25,No.11,(2001),pp.1117-24,ISSN 1423-0313

Gorgen, M.; Turatti, K. \& Medeiros, AR. (2005). Aqueous extract of Ilex paraguariensis decreases nucleotide hydrolysis in rat blood serum. J Ethnopharmacol Vol.97, No.1, (Feb 2005), pp.73-7, ISSN: 1539-3704

Greenspan, HC.; Aruoma, OI. \& Arouma, O. (1994). Could oxidative stress initiate programmed cell death in HIV infection? A role for plant derived metabolites having synergistic antioxidant activity. Chem Biolnteract Vol.91, No.2-3, (Jun 1994), pp. 187-97, ISSN 1421-9794

Groom, ST.; Johns, T. \& Oldfield, PR. (2007). The potency of immunomodulatory herbs may be primarily dependent upon macrophage activation. J Med Food Vol.10, No.1, (Mar 2007), pp.73-9. ISSN: 1096-620X

Ghulam-Abbas, Z.; Lutale, JK.; Morbach, S. \& Archibald, LK. (2002). Clinical outcome of diabetes patients hospitalized with foot ulcers, Dar el Salaam, Tanzania. Diabet Med Vol.19, No.7 (Jul 2002), pp.575-9, ISSN: 1464-5491

Gupta, V.; Gupta, A.; Saggu, S.; Divekar, HM.; Grover, SK. \& Kumar, R. (2005). Anti-stress and adaptogenic activity of 1-arginine supplementation. Evid Based Complement Alternat Med Vol.2, No.1, (Dec 2004), pp.93-7, ISSN 1741-4288

Gurwitsch, AG. (1991). Principles of Analytical Biology and of the Theory of Cellular Fields. Nauka, ISBN 90-806902-1-X, Moscow

Haken, H. (2000). Information and Self-Organization. A Macroscopic Approach to Complex Systems. Springer-Verlag, ISBN 0-521-62436-3, New York, USA

Halim, AB.; el-Ahmady, O.; Hassab-Allah, S.;Abdel-Galil, F.; Hafez, Y. \& Darwish, D. (1997).Biochemical effect of anti-oxidants on lipids and liver function in experimentally-induced liver damage. Ann Clin Biochem Vol.34, Part 6, (Nov 1997), pp.656-63, ISSN 1758-1001

Han, SB.; Yoon, YD.; Ahn, HJ.; Lee, HS.; Lee, CW.; Yoon, WK.; Park, SK. \& Kim, HM. (2003). Toll-like receptor-mediated activation of $\mathrm{B}$ cells and macrophages bypolysaccharide isolated from cell culture of Acanthopanax senticosus. Int Immunopharmacol Vol.3, No.9, (Sep 2003), pp.1301-12, ISSN 1567-5769

Heims SJ, von Neumann J, Wiener N. (1980). From Mathematics to the Technologies of Life and Death. MIT Press, ISBN 0262081059, Cambridge, USA

Hercberg, S.; Galan, P.; Preziosi, P.; Bertrais, S.; Mennen, L.; Malvy, D.; Roussel, AM.; Favier, A. \& Briançon, S. (2004). The SU.VI.MAX Study: a rando-mized, placebocontrolled trial of the health effects of antioxidant vitamins and minerals. Arch Intern Med Vol.164,No.21,(Nov 2004), pp.2335-42. ISNN 0003-9926

Hirata, Y.; Soeki, T.; Aikake, M.; Sakai, Y.; Igarashi, T. \& Sata, M. (2009). Synthetic prostacycline agonist, ONO-131, ameliorates left ventricular dysfunction and cardiac fibrosis in cardiomyopathic hamsters. Biomed Pharmacother Vol.63, No.19, (Sept 2009), pp 781-6, ISSN 1950-6007

Hong, CH.; Hur, SK.; Oh, OJ.; Kim, SS.; Nam, KA. \& Lee, SK. (2002). Evaluation of natural products on inhibition of inducible cyclooxigenase (COX-2) and nitric oxide synthase (iNOS) in cultured mouse macrophage cells. J Ethnopharmacol Vol.83, No.1-2, (Nov 2002), pp.153-9. ISSN 0378-8741 
Hong, L.; Xun, M. \& Wutong, W. (2007). Anti-diabetic effect of an alpha-glucan from fruit body of maitake (Grifola frondosa) on KK-Ay mice. J Pharm Pharmacol. Vol.59, No.4, (Apr 2007), pp.575-82. ISSN 0022-3573

Houpt, JB.; Mc Millan, R.; Wein, C. \& Paget-Dellio, SD. (1999). Effect of Glucosamine Hydrochloride in the treatment of pain of osteoarthritis of the knee. J Rheumatol Vol.26,No.11,(Nov 1999), pp.2423-30, 0315-162X

Huang, W.; Ye, X.; Li, X.; Zhao, Z.; Lan, P.; Wang, L.; Liu, M.; Gao, Y.; Zhu J.; Li, P.\& Feng, P. (2010). [The inhibition activity of chemical constituents in hawthorn fruit and their synergistic action to HMG-CoA reductase]. Zhongguo Zhong Yao Za Zhi Vol.35,No.18,(Sept 2010),pp.2428-31, ISSN 1001-5302

Iguchi, K.; Okumura, N.; Usui, S.; Sajiki, H.; Hirota, K. \& Hirano, K. (2001). Myristoleic acid, a cytotoxic component in theextract from Serenoa repens, induces apoptosis and necrosis in human prostatic LNCaP cells. Prostate Vol.47, No.1, (Apr 2001), pp.5965, ISSN 0270-4137

Incandela, L.; Cesarone, MR. \& Cacchio, M. (2001). Total triterpenic fraction of Centella asiatica in chronic venous insufficiency and in high-perfusion microangiopathy. Angiology Vol.52, Suppl.2,(Oct 2001),pp.S9-13, ISSN 0003-3197

Izzo, AA.; Di Carlo, G.; Borrelli, F. \& Ernst, E. (2005). Cardiovascular pharmacotherapy and herbal medicines: the risk of drug interaction. Int J Cardiol Vol.98, No. (Jun 2006), pp.1-14. ISSN: 0167-5273

Jang, MH.; Jun DO.; Rue, SW.; Han, K.; Park, W. \& Kim, YH. (2001). Arginine antimetabolite 1-canavanine induces apoptotic cell death in human Jurkat T cells via caspase-3 activation regulated by Bcl-2 or Bcl-xL. Biochem Biophys Res Commun Vol.295, No.2,(Jul 2002),pp.283-8, 0006-291X

Järvisalo, MJ.; Jartti, L.; Nänto-Salonen, K.; Irjala, K.; Rönnemaa, T.; Hartiala, JJ.; Celermajer, DS.\& Raitakari, OT. (2001). Increased aortic intima-media thickness: a marker of preclinical atherosclerosis in high-risk children. Circulation Vol.104, No.24,(Dec 2001), pp.2943-2947, ISSN 1524-4539

Ji, YB.; Gao, SY. \& Zhang, XJ. (2004). [Influence of Sargassum fusiforme polysaccharide on apoptosis of tumor cells]. Zhongguo Zhong Yao Za Zhi Vol.29,No.3, (Mar 2004),pp.245-7, ISSN 1001-5302

Jiang, J.; Slivova, V.; Valachovicova, T.; Harvey, K. \& Sliva, D. (2004). Ganoderma lucidum inhibits proliferation and induces apoptosis in human prostate cancer cells PC-3. Int J Oncol Vol.24, No.5, (May 2004),pp.1093-9, ISSN 1019-6439

Jing, SB.; Li, L.; Ji, D.; Takiguchi, Y. \& Yamaguchi, T. (1997). Effect of chitosan on renal function in patients with chronic renal failure. J Pharm Pharmacol Vol.49,No.7,(Jul 1997),pp.721-3, ISSN 0022-3573

Jung, KH.; Ha, E.; Kim, MJ.; Uhm, YK.; Kim, HK.; Hong, SJ.; Chung, JH. \& Yim, SV. (2006). Ganoderma lucidum extract stimulates glucose uptake in L6 rat skeletalmuscle cells. Acta Biochim Pol Vol.53,No.3,(Sep 2006),pp.597-601, 0001-527X

Jurkstiene, V.; Kondrotas, AJ. \& Kevelaitis, E. (2004). [Compensatory reactions of immune system and action of Purple Coneflower (Echinacea purpurea L.) (Moench) preparations]. Medicina (Kaunas) Vol.40,No.7,(2004),pp.657-62,ISSN 1648-9144

Katerere, DR. \& Eloff, JN. (2005). Antibacterial and antioxidant activity of Sutherlandia frutescens (Fabaceae), a reputed anti-HIV/AIDS phytomedicine. Phytother Res Vol.19,No.9, (Sept 2005), pp.779-81. ISSN 0951-418X 
Khasina, EI.; Dardymov, IV. \& Brekhman, II. (1983). [Effects of Eleutherococcus extract on the re-adaptation processes after 7 hour hypokinesia in rats]. Kosm Biol Aviakosm Med Vol.17, No.5, (Sept-Oct 1983),pp.55-8, ISSN 0321-5040

Kidd, PM. The use of mushrooms glucans and proteoglycans in cancer treatment. Altern Med Rev 2000 Vol.5, No. 1, (Feb 2000),pp.4-27, ISSN 1089-5159

Kim, HS.; Kacew, S. \& Lee, BM. (1999). In vitro chemopreventive effects of plant polysaccharides (Aloe barbadensis miller, Lentinus edodes, Ganoderma lucidum and Coriolus versicolor. Carcinogenesis Vol.20,No.8,(Aug 1999),pp.1637-40, ISSN 01433334

Kim, KS.; Choi, YH.; Kim, KH.; Lee, YC.; Kim, CH.; Moon, SH.; Kang, SG. \& Park, YG. (2004). Protective and anti-arthritic effects of deer antler aqua-acupunture (DAA), inhibiting dihydroorotate dehydrogenase, on phosphate ionsmediated chondrocyte apoptosis and rat collagen-induced arthritis. Int Immunopharmacol Vol.4,No.7,(Jul 2004), pp.963-73, ISSN 1567-5769

Kim, LS.; Waters, RF.\& Burkholder, PM. (2002). Immunological activity of larch arabinogalactan and Echinacea: a preliminary, randomized, double-blind, placebocontrolled trial. Altern Med Rev Vol.7,No.2, (Apr 2002),pp.138-49, ISSN 1089-5159

Kim, MJ.; Yoo, KH.; Kim, JH.; Seo, YT.; Ha, BW.; Kho, JH.; Shin, YG. \& Chung, CH.(2007).Effect of pinitol on glucose metabolism and adipocytokines in uncontrolledtype 2 diabetes. Diabetes Res Clin Pract Suppl.1,(Apr 2007), pp.S247-51, ISSN: 01688227

Kim, S.; Kubec, R. \& Musah, RA. (2005). Antibacterial and antifungal activity of sulfurcontaining compoundsfrom Petiveria alliacea L. J Ethnopharmacol Vol.104,No.12,(Mar 2006),pp.188-92, ISSN 0378-8741

Kobayakawa, J. \& Sato-Nishimori, F. (2004). G2-M arrest and antimitotic activity mediated by casticin, a flavonoid isolated from Viticis Fructus (Vitex rotundifolia Linne fil.). Cancer Lett Vol.208, No.1,(May 2004),pp.59-64, ISSN 0304-3835

Kobayashi, M.; Devaraj, B.; Usa, M.; Tanno, Y.; Takeda, M. \& Inaba, H (1996). Development and applications of new technology for two-dimensional space-time characterization and correlation analysis of ultraweak biophoton information. Front Med Biol Eng Vol.7,No.4,(1996),pp.299-309, 0921-3775

Kodama, N.; Murata, Y. \& Nanba, H. (2004). Administration of a polysaccharide from Grifola frondosa stimulates immune function of normal mice. $J$ Med Food Vol.7,No.2,(2004),pp.141-5, ISSN 1096-620X

Kohguchi, M.; Kunikata, T.; Watanabe, H.; Kudo, N.; Shibuya, T.; Ishihara, T.; Iwaki, K.; Ikeda, M.; Fukuda, S. \& Kurimoto, M. (2004).Immuno-potentiating effects of the antler shaped fruiting body of Ganoderma lucidum. Biosci Biotechnol Biochem Vol.68,No.4,(Apr 2004),pp.881-7, ISSN 0916-8451

Kormosh, N.; Laktionov, K. \& Antoshechkina, M. (2006). Effect of a combination of extract from several plants on cell-mediated and humoral immunity of patients with advanced ovarian cancer. Phytother Res Vol.20,No.5,(May 2006),pp.424-5,ISSN 0951$418 \mathrm{X}$

Korotkov, K.; Williams, B. \& Wisneski, LA. (2004).Assessing biophysical energy transfer mechanisms in living systems: the basis of life processes. J Altern Complement Med Vol.10,No.1,(Feb 2004),pp.49-57, ISSN 1075-5535 
Korotkov, K. (1988). Light after Life. Backbone Publishing Co., ISBN 0-9644311-5-7 Fair Lawn, USA

Kotsiuruba, AV.; Bukhanevych, OM.; Tarakanov, SS. \& Kholodova, IuD. (1993). [Modulation of intracellular pools of cyclic purine nucleotides by biologically active oxysterol-ecdysterone and vitamin D3]. Ukr Biokhim Zh Vol.65,No.5,(Sep-Oct 1993),pp.76-83, ISSN 0201-8470

Kristiansen, OP.; Mandrup-Poulsen T. (2005). Interleukin-6 and diabetes: the good, the bad, or the indifferent? Disbetes Vol.2 Suppl.1(2005),pp.S114-124, ISSN

Kubota, Y.; Tanaka, N.; Umegaki, K.; Takenaka, H.; Mizuno, H.; Nakamura, K.; Shinozuka, K.\& Kunitomo, M. (2001). Gingko biloba extract induced relaxation of rat aorta is associated with increase in endothelial intracellular calcium level. Life Sci Vol.69,No.20,(Oct 2001),pp.2327-36, ISSN 0024-3205

Kundu, JK.; Mossanda, KS.; Na, HK. \& Surh, YJ. (2005). Inhibitory effects of the extracts of Sutherlandia frutescens (L.) R. Br. and Harpagophytum procumbens DC. on phorbol ester-induced COX-2 expression in mou-se skin: AP-1 and CREB as potential upstream targets. Cancer Lett Vol.218,No.1,(Jan 2005),pp.21-31,ISSN 0304-3835

Kuo, CL.; Chi, CW. \& Liu, TY.(2004).The anti-inflammatory potential of berberine in vitro and in vivo. CancerLett Vol.203,No.2,(Jan 2004),pp.127-37,ISSN 0304-3835

Kutuzova, NM.; Filippovich, IuB.; Kholodova, IuD. \& Miladera, K. (1991). [Ecdysterone induces the activity of multiple forms of acid phosphatase and malate dehydrogenase]. Ukr Biokhim Zh Vol.63,No.3,(May-Jun 1991),pp.41-5,ISSN 02018470

Labay, V.; Raz, T.; Baron, D.; Mandel, H.; Williams, H.; Barrett, T.; Szargel, R.; McDonald, L.; Shalata, A.; Nosaka, K.; Gregory, S. \& Cohen, N.(1999). Mutations in SIC19A2 cause thiamine-responsive megaloblastic anaemia associated with diabetes mellitus and deafness. Nat Genet Vol.22, No.3,(Jul 1999),pp.300-304, ISSN 1061-4036

Lacaille-Dubois, MA.; Franck, U. \& Wagner, H. (2001). Search for potential angiotensin converting enzyme (ACE)-inhibitors from plants. Phytomedicine Vol.8,No.1,(Jan 2001),pp.47-52,ISSN 0944-7113

Ladriere, L.; Laghmich, A.; Malaisse-Lagae, F. \& Malaisse, WJ. (1997). Effect of dehydroepiandrosterone in hereditarily diabetic rats. Cell Biochem Funct Vol.15,No.4,(Dec 1997),pp.287-92,ISSN 0263-6484

Laszlo, E. (1987). Evolution, The Grand Synthesis. Shambhala Publications Inc., ISBN 288124-491-2,Boston,USA

Lavery, LA.; Armstrong, DG. \& Harkless, LB. (1997). Classification of diabetic foot wounds. Ostomy Wound Manage Vol.43,No.2, (Mar 1997),pp.44-8, 50, 52-3, ISSN 0889-5899

Lavery, La.; Armstrong, DG.; Wunderlich. RP.; Tredwell, J. \& Boulton, AJ. (2003). Diabetic Foot Syndrome: Evaluating the prevalence and incidence of foot pathology in Mexican American and non-Hispanic whites from a diabetes management cohort. Diabetes Care Vol.26, No.5,(May 2003),pp.1435-1438, ISSN 0149-5992

Lee, SE.; Ju, EM. \& Kim, JH. (2001). Free radical scavenging and antioxidant enzyme fortifying activities of extracts from Smilax china root. Exp Mol Med Vol.33,No.4(Dec 2001),pp.263-8,ISSN 1226-3613

Lee, SY. \& Rhee, HM.(1990).Cardiovascular effects of mycelium extract of Ganoderma lucidum: inhibition of sympathetic outflow as a mechanism of its hypotensive action. Chem Pharm Bull (Tokyo) Vol.38,No.5,(May 1990),pp.1359-64,ISSN 0009-2363 
Leff, HS. \& Rex, AF. (eds). (1990). Maxwell's Demon: Entropy, Information, Computing. Princeton University Press, ISBN 0-7503-0759-5,Princeton, USA

Lehto, S.; Ronnemaa, T.; Pyorala, K. \& Laakso, M.(1996). Risk factors predicting lower extremity amputations in patients with NIDDM. Diabetes Care Vol.19,No.6,(Jun 1996),pp.607-612, ISSN: 0149-5992

Leu, SF.; Chien, CH.; Tseng, CY.; Kuo, YM. \& Huang, BM. (2005). The in vivo effect of Cordyceps sinensis mycelium on plasma corticosterone level in male mouse. Biol Pharm Bull Vol.28,No.9,(Sep 2005),pp.1722-5, ISSN 0918-6158

Li, CJ.; Wang, C. \& Pardee, AB.(1995). Induction of apoptosis by b-lapachone in human prostate cancer cells. Cancer Res Vol.55,No.17,(Sep 1995),pp.3712-5,ISSN 0008-5472

Lin, H.; She, YH.; Cassileth, BR.; Sirotnak, F.\& Cunningham Rundles, S. (2004).Maitake betaglucan MD-fraction enhances bone marrow colony formation and reduces doxorubicin toxicity in vitro. Int Immunopharmacol Vol.4,No.1, (2004),pp.91-9, ISSN 1567-5769

Lindley, D. (2001).Boltzmann's Atom: The Great Debate that Launched a Revolution in Physics. Free Press, ISBN 0-684-85186-5, New York, USA

Ling, S.; Nheu, L.; Dai, A.; Guob, Z. \& Komaseroff, P.(2008). Effects of four medicinal herbs on human vascular endothelial cells in culture. Int J Cardiol Vol.128,No.3,(Aug 2008), pp.350-58, ISSN: 1874-1754

Lishmanov, IuB.; Naumova, AV.; Afanas'ev, SA. \& Maslov LN.(1997).[Contribution of the opioid system to realization ofinotropic effects of Rhodiola rosea extracts in ischemic and reperfusion heart damage in vitro]. Eksp Klin Farmakol Vol.60,No.3,(May-Jun 1997),pp.34-6,ISSN 0869-2092

Liu, JC.; Chan, P.; Chen, YJ.; Tomlinson, B.; Hong, SH. \& Cheng, JT.(1999). The antihypertensive effect of the berberine derivative 6-protoberberine in spontaneously hypertensive rats. Pharmacology Vol.59,No.6,(Dec 1999),pp.2839,ISSN 0031-7012

Liu,TP.; Lee, CS.; Liou, SS. \& Cheng, JT.(2005). Improvement of insulin resistance by Acanthopanax senticosus root infructose-rich chow-fed rats. Clin Exp Pharmacol Physiol Vol.32,No.8,(Aug 2005),pp.649-54, ISSN 0305-1870

Lopez-Fando, A.; Gomez-Serranillos, MP.; Iglesias, I.; Lock, O.; Upamayta, UP. \& Carretero, ME. (2004). Lepidium peruvianum chacon restores homeostasis impaired by restraint stress. Phytother Res Vol.18,No.6,(2004),pp.471-4,ISSN 0951-418X

Lores, RI. \& Cires Pujol, M.(1990). Petiveria alleaceae L.(anamu). Study of the hypoglycemic effect. Med Interne Vol.28, No.4,(Oct-Dec 1990),pp.347-52, ISSN 0377-1202

Lu, L.; Ying, K.; Wei, S.; Fang, Y.; Liu, Y.; Lin, H.; Ma, L. \& Mao, Y.(2004). Asiaticoside induction for cell-cycle progression, proliferation and collagen synthesis in human dermal fibroblasts. Int J Dermatol Vol.43,No.11,(Nov 2004),pp.801-7, ISSN 0011-9059

Luo, XY.; Zhang, FR. \& He, RM. (2009) [Efficacy of shenfu injection as adjuvant therapy in treating patients of ischemic cardiomyopathy with Heart insufficiency] Zhuongguo Zhong Xi Yi Jie He Za Zhi Vol.29,No.8,(Aug 2009),pp.685-7,ISSN 1003-5370

Ma, T.; Qi, QH.; Xu, J.; Dong, ZL. \& Yang, WX. (2004). Signal pathways involved in emodininduced contraction of smooth muscle cells from rat colon. World J Gastroenterol Vol.10,No.10,(May 2004),pp.1476-9, ISSN 1007-9327

Malay, DS.; Margolis, DJ.; Hoffstad, OJ. \& Bellamy, S.(2006). The incidence and risks of failure to heal after lower extre- mity amputation for the treatment of diabetic 
neuropathic foot ulcer. J Foot Ankle Surg Vol.45,No.6,(Nov-Dec 2006),pp.36674,ISSN 1542-2224

Malpezzi, EL.; Davino, SC.; Costa, LV.; Freitas, JC.; Giesbrecht, AM. \& Roque, NF. (1994). Antimitotic action of extracts of Petiveria alliacea on sea urchin egg development. Braz J Med Biol Res Vol.27,No.3,(Mar 1994),pp.749-54,ISSN 1414-431X

Marrero, S.; Martínez, A. \& González, S. (2006). [Correlation between diabetic foot degree and type of amputation in a Public Medical Assistance Center] Informe médico. Vol.8,No.4, (2006),pp.169-177, ISSN 13169688

Maslova, LV.; Kondrat'ev, Blu.; Maslov, LN. \& Lishmanov, IuB. (1994). [The cardioprotective and antiadrenergic activity of an extract of Rhodiola rosea in stress]. Eksp Klin Farmakol Vol.57,No.6,(Nov-Dec 1994),pp.61-3, ISSN 0869-2092

Matsuda, T.; Kuroyanagi, M. \& Sugiyama, S. (1994). Cell differentiation-inducing diterpenes from Andrographis paniculata Nees. Chem Pharm Bull (Tokyo) Vol.42,No.6(Jun 1994), pp.1216-25, ISSN 0009-2363

Mei, QB.; Tao, JY. \& Cui, B. (1991). Advances in the pharmacological studies of radix Angelica sinensis (Oliv.) Diels (Chinese danggui). Chin Med J Vol.104,No.9(Sept 1991),pp.776-81, ISSN 0366-6999

Miyajima, S.; Shirai, A.; Yamamoto, S.; Okada, N. \& Matsushita, T.(2005). Risk factors for major limb amputations in diabetic foot gangrene patients. Diabetes Res Clin Pract Vol.71,No.3,(Mar 2006),pp.272-9, ISSN 0168-8227

Moon, DO.; Choi, YH.; Kim, ND.; Park, YM. \& Kim, GY.(2007). Anti-inflammatory effects of beta-lapachone in lipo polysaccharide estimulated BV2 microglia. Int Immunopharmacol Vol.7, No.4,(Apr 2007),pp.506-14, ISSN 1567-5769

Moss, SE.; Klein, R. \& Klein, B. (1996). Long-term incidence of lower-extremity amputations in a diabetic population. Arch Fam Med Vol.5,No.7,(Jul-Aug 1996),pp.391-398, ISSN 1063-3987

Naik, Gh.; Priyadarsini, KI.; Satav, JG.; Banavalikar, MM.; Sohoni, DP.; Biyani, MK. \& Mohan, H. (2003). Comparative antioxidant activity of individual herbal components used in Ayurvedic medicine. Phytochemistry Vol.63,No.1,(May 2003),pp.97-104, ISSN 0031-9422

Neufeldt V, Guralnik D (eds). (1988) Webster's New World Dictionary. Simon \& Schuster, New York, USA

Nyamu, PN.; Otieno, CF.; Amayo, EO. \& McLigeyo, SO. (2003). Risk factors and prevalence of diabetic foot ulcers at Kenyatta National Hospital, Nairobi. East Afr Med J Vol.80,No.1(Jan 2003),pp36-43, ISSN 0012-835X

Odama, N.; Murata, Y. \& Nanba, H. (2004). Administration of a polysaccharide from Grifola frondosa stimulates immune function of normal mice. $J$ Med Food Vol.7,No.2,(2004),pp.141-5, ISSN 1096-620X

Ohyama, K.; Akaike, T. \& Hirobe, C. (2003). Cytotoxicity and apoptotic inducibility of Vitex agnus-castus fruit extract in cultured human normal and cáncer cells and effect on growth. Biol Pharm Bull Vol.26,No.1,(Jan 2003),pp.10-8, ISSN 0918-6158

Olalde, JA.; Magarici, M.; Amendola, F.; del Castillo, O.; Gonzalez, S. \& Muhammad, A. (2008) Clinical outcomes of diabetic foot management with Circulat. Phytother Res Vol.22,No.10,(Oct 2008),pp.1292-8, ISSN: 1099-1573 
Olalde Rangel, JA.; Magarici, M.; Amendola, F. \& del Castillo, O. (2005). The Systemic Theory of Living Systems. Part IV: Systemic Medicine-The Praxis. Vol.2,No.4,(Dec 2005),pp. 429-439, ISSN 1741-4288

Olalde Rangel, JA. (2005). The Systemic Theory of Living Systems and Relevance to CAM: the Theory (Part III). Evid Based Complement Alternat Med Vol.2,No.3,(Sept 2005),pp.267-275, ISSN 1741-4288

Olalde Rangel, JA. (2005). The Systemic Theory of Living Systems and Relevance to CAM: The Theory (PartII). Evid Based Complement Alternat Med Vol.2,No.2,(Jun 2005),pp.129-137, ISSN 1741-4288

Olalde Rangel, JA. (2005). The Systemic Theory of Living Systems and Relevance to CAM: Part I: The Theory.Evid Based Complement Alternat Med Vol.2,No.1(Mar 2005),pp.1318, ISSN 1741-4288

Owens, J. \& Van de Castle, R. (2004). Gas Discharge Visualization Technique: Introduction to the concept of Energy Fields. In: Measuring Energy Fields, K. Korotkov, (Ed.), 11-22, Backbone Publishing, ISBN 097420191,Fair Lawn, USA

Palsdottir, A.; Cross, SJ.; Edwards, JH. \& Carrol, MC. (1983). Correlation between a DNA restriction fragment length polymorphism and C4A6 protein. Nature Vol.306,No.5943,(Dec 1983),pp.615-616, ISSN 0028-0836

Park, EK.; Choo, MK.; Han, MJ. \& Kim, DH. (2004). Ginsenoside Rh1 possesses antiallergic and anti-inflammatory activities. Int Arch Allergy Immunol Vol.133,No.2,(Feb 2004),pp.113-20, ISSN 1018-2438

Park, SH.; Lee, SG.; Kang, SK. \& Chung, SH. (2006). Acanthopanax senticosus reverses fatty liver disease and hyperglycemia in ob/ob mice. Arch Pharm Res Vol.29,No.9,(Sept 2006),pp.768-76, ISSN 0253-6269

Pena, JC. (2002). [The concept of illness and kidney diseases in Nahuatl medicine. Synthesis of Mesoamerican pre-Columbian medicine]. Rev Invest Clin Vol.54,No.5,(Sep-Oct 2002),pp.474-81,ISSN 0034-8376

Pepe, C.; Rozza, A. \& Veronesi, G. (1999). The evaluation by video capillaroscopy of the efficacity of a Gingko biloba extract with l-arginine and magnesium in the treatment of trophic lesions in patients with stage-IVchronic obliterating arteriopathy. Minerva Cardioangiol Vol.47,No.6,(Jun 1999),pp.223-30, ISSN 0026-4725

Pereira, EM.; Machado T, de B.; Leal, IC.; Jesus ,DM.; Damaso, CR.; Pinto, AV.; GiambiagideMarval, M.; Kuster, RM. Santos, \& KR.(2006).Tabebuia avellanedae naphthoquinones: activity against methicillin-resistant staphylococcal strains, cytotoxic activity and in vivo dermal irritability analysis. Ann Clin Microbiol Antimicrob Vol.22(Mar 2006),pp.5, ISSN 1476-0711

Pinello, KC.; Fonseca, Ede S.; Akisue, G.; Silva, AP.; Salgado Oloris, SC.; Sakai, M.; Matsuzaki, P.; Nagamine, MK.; Palermo Neto, J. \& Dagli, ML. (2005). Effects of Pfaffia paniculata (Brazilian ginseng) extract on macrophage activity. Life Sci Vol.78,No.12,(Feb 2006),pp.1287-92 ISSN: 0024-3205

Piscoya, J.; Rodriguez, Z.; Bustamante, SA.; Okuhama, NN.; Miller, MJ. \& Sandoval, M .(2001). Efficacy and safety of freeze-dried cat's claw in osteo-arthritis of the knee: mechanisms of action of species Uncaria guianensis. Inflamm Res Vol.50,No.9,(Sept 2001),pp.442-8,ISSN 1023-3830

Planchon, SM.; Wuerzberger, S.; Frydman, B.; Witiak, DT.; Hutson, P.; Church DR.; Wilding, G. \& Boothman, DA. (1995). b-Lapachone-mediated apoptosis in human 
promyelocytic leuke-mia (HL-60) and human prostate cancer cells: a p53independent response. Cancer Res Vol.55,No.17(Sept 1995),pp.3706-11, ISSN 00085472

Plotnikov, MB.; Aliev, OI.; Vasil'ev, AS.; Maslov, MIu.; Dmitruk, SE. \& Krasnov, EA. (2001). [Effect of Rhaponticum carthamoides extract on hemorheological properties of blood in rats with arterial hypertension]. Eksp Klin Farmakol Vol.64,No.6,(Nov-Dec 2001),pp.45-7, ISSN 0869-2092

Popiela, T.; Kulig, J.; Hanisch, J. \& Bock, PR. (2001). Influence of a complementary treatment with oral enzymes on patients with colorectal cancers-an epidemiological retrolective cohort study. Cancer Chemother Pharmacol Vol.47,Suppl.1,(Jul 2001),pp.S55-63, ISSN 0344-5704

Popp, FA. (2003). Properties of biophotons and their theoretical implications. Indian J Exp Biol Vol.41,No.5, (May 2003),pp.391-402, ISSN 0019-5189

Prigogine, I. (1984). Order Out of Chaos. Bantam Books, ISBN 0553340824, New York, USA

Puri, A.; Saxena, R.;Saxena, RP.; Saxena, KC.; Srivastava, V. \& Tandon, JS. (1993). Immunostimulant agents from Andrographis paniculata. J Nat Prod Vol.56,No.7,(Jul 1993),pp.95-9, ISSN 0163-3864

Randolph, RK.; Gellenbeck, K.; Stonebrook, K.; Brovelli, E.; Qian, Y.; Bankaitis-Davis, D. \& Cheronis, J. (2003). Regulation of human immune gene Expression as influenced by a commercial blended Echinacea product: preliminary studies. Exp Biol Med (Maywood) Vol.228,No.9,(Oct 2003),pp.1051-6, ISSN 1535-3702

Raso, GM.; Pacilio, M.; Di Carlo, G.; Esposito, E.; Pinto, L. \& Meli, R.(2002). In-vivo and invitro anti-inflammatory effect of Echinacea purpurea and Hypericum perforatum. J Pharm Pharmacol Vol.54,No.10,(Oct 2002),pp.1379-83, ISSN 0022-3573

Ratzmann, KP.; Drzimalla, E. \& Raskovic, M. (1994). [The "diabetic foot" syndrome. Association with other complications and the incidence of amputation] Med Klin (Munich) Vol.89,No.9 (Sept 1994),pp.469-72, ISSN 0723-5003

Rayman, G.; Krishnan, ST. \& Baker, NR. (2004). Are we underestimating diabetes-related lower-extremity amputation rates? Results and benefits of the first prospective study. Diabetes Care Vol.27,No.8,(Aug 2004),pp.1892-6,ISSN 0149-5992

Reay, JL.; Kennedy, DO. \& Scholey, AB. (2005). Single doses of Panax ginseng (G115) reduce blood glucose levels and improve cognitive performance during sustained mental activity. J Psychopharmacol Vol.19,No.4(Jul 2004),pp.357-65, ISSN 0269-8811

Redman, DA. (2000). Ruscus aculeatus (butcher's broom) as a potential treatment for orthostatic hypotension, with a case report. I Altern Complement Med Vol.6,No.6,(Dec 2000),pp.539-49,ISSN 1075-5535

Rehman, J.; Dillow, JM.; Carter, SM.; Chou, J.; Le, B. \& Maisel, AS. (1999). Increased production of antigen-specific immunoglobulins $G$ and $M$ following in vivo treatment with the medicinal plants Echinacea angustifolia and Hydrastis canadensis. Immunol Lett Vol.68,No.2-3(Jun 1999),pp.391-5, ISSN 0165-2478

Rigelsky, JM. \& Sweet, BV. (2002).Hawthorn: pharmacology and therapeutic uses. Am J Health Syst Pharm Vol.59,No.5 (Mar 2002),pp.417-22, ISSN: 1079-2082

Risco, E.; Ghia, F.; Vila, R.; Iglesias, J.; Alvarez, E. \& Canigueral, S. (2003). Immunomodulatory activity and chemical characterisation of sangre de drago (dragon's blood) from Croton lechleri. Planta Med Vol.69,No.9,(Sept 2003),pp.785-94, ISSN 0032-0943 
Rotshteyn, Y. \& Zito, SW. (2004). Application of modified in vitro screening procedure for identifying herbals possessing sulfonylurea-like activity. I Ethnopharmacol Vol.93,No.2-3,(Aug 2004),pp.337-44, ISSN 0378-8741

Ruffa, MJ.; Ferraro, G.; Wagner, ML.; Calcagno, ML.; Campos, RH. \& Cavallaro, L. (2002). Cytotoxic effect of Argentine medicinal plant extracts on human hepatocellular carcinoma cell line. J Ethnopharmacol Vol. 79,No.3(Mar 2002),pp.335-9, ISSN 03788741

Santa Maria-Margalef, A.; Paciucci Barzanti, R. \& Reventos Puigjaner, J. (2003). Antimitogenic effect of Pygeum africanum extracts on human prostatic cancer cell lines and explants from benign prostatic hyperplasia. Arch Esp Urol Vol.56,No.4,(May 2003),pp.369-78, ISSN 0004-0614

Sasagawa, M.; Cech, NB.; Gray, DE.; Elmer, GW. \& Wenner, CA. (2006). Echinacea alkylamides inhibit interleukin-2 production by Jurkat T cells. Int Immunopharmacol Vol.6,No.7,(Jul 2006),pp.1214-21,ISSN 1567-5769

Savickiene, N.; Dagilyte, A. \& Lukosius, A. (2002). Importance of biologically active components and plants in the pre-vention of complications of diabetes mellitus. Medicina (Kaunas) Vol.38,No.10(2002),pp.970-5, ISSN1010-660X

Scazzocchio, F.; Cometa, MF.; Tomassini, L. \& Palmery, M. (2001). Antibacterial activity of Hydrastis canadensis extract and its major isolated alkaloids. Planta Med Vol.67,No.6,(Aug 2001),pp.561-4, ISSN 0032-0943

Selye, H. (1976). Stress of Life. McGraw-Hill, New York, USA

Shannon, CE. \& Weaver, W. (1999).The Mathematical Theory of Communication, University of Illinois Press, ISBN 0-387-95457-0, Champaign, USA

Shao, BM.; Xu, W. \& Dai, H. (2004). A study on the immune receptors for polysaccharides from the roots of Astragalus membranaceus, a Chinese medicinal herb. Biochem Biophys Res Commun Vol.320,No.4,(Aug 2004),pp.1103-11, ISSN 0006-291X

Shealy, CN. (1999). Natural Progesterone. Safe and Natural Hormone Replacement, Keats Publishing, ISBN 10-0879838892, Los Angeles,USA

Sheng, Y.; Pero, RW. \& Amiri, A. (1998). Induction of apoptosis and inhibition of proliferation in human tumor cells treated with extracts of Uncaria tomentosa. Anticancer Res Vol.18,No.5A, (Sept-Oct 1998), pp.3363-8, ISSN 0250-7005

Schroedinger, E. (1992).What is Life? Cambridge University Press, Cambridge, USA

Siqueira, IR.; Fochesatto, C.; da Silva, AL.; Nunes, DS.; Battastini, AM.; Netto, CA. \& Elisabetsky, E. (2003). Ptychopetalum olacoides, a traditional Amazonian "nerve tonic", possesses anticholinesterase activity. Pharmacol Biochem Behav Vol.75, No.3,(Jun 2003),pp.645-50, ISSN 0091-3057

Slawinska, D. \& Slawinski, J. (1987). Ultraweak photon emission in model reactions of the in vitro formation of eumelanins and pheomelanins. Pigment Cell Res Vol.1,No.3,(1987),pp.171-5, ISSN 0893-5785

Smolina, TP.; Solov'eva, TF. \& Besednova, NN. (2001). [Immunotropic activity of panaxans-bioglycans isolated from ginseng] Antibiot Khimioter Vol.46,No.7, (2001),pp.19-22, ISSN 0235-2990

Spasov, AA.; Wikman, GK.; Mandrikov, VB.; Mironova, IA \& Neumoin, VV. (2000). A double-blind, placebo controlled pilot study of the stimulating and adaptogenic effect of Rhodiola rosea SHR-5 extract on the fatigue of students caused by stress 
during an examination period with a repeated low-dose regimen. Phytomedicine Vol.7,No.2,(Apr 2000),pp.85-9, ISSN 0944-7113

Stonier T. (1996). Information as a basic property of the universe. Biosystems Vol.38, No.23,(1996),pp.135-40, ISSN: 0303-2647

Sugimura, H. (1989). Effects of aqueous extracts from Eleutherococcus on the oxidative enzyme activities in mouse skeletal muscle. Annual Proceedings of the Gifu Pharmaceutical University Vol.38(1989)pp.38-48.

Sun, T. \& Zhu, Y. (1999). The effect of PSP on immune function and living quality in patients receiving chemotherapy for gynecological malignancies. In: Advanced Research in PSP, Q. Yang (Ed.), 308-9, Hong Kong Association for Health Care Ltd, Hong Kong

Sun, Z.; Yang, Q. \& Fei, H. (1999). The ameliorative effect of PSP on the toxic and side reactions of chemo and radiotherapy of cancers. In: Advanced Research in PSP, Q. Yang (Ed.), 304-7, Hong Kong Association for Health Care Ltd, Hong Kong

Takeda, K. and Okomura, K.(2004) CAM and NK cells. Evid Based Complement Alternat Med Vol.1,No.1,(Jun 2004), pp.17-27, ISSN 1741-4288

Takeda, M.; Tanno, Y.; Kobayashi, M.; Usa, M.; Ohuchi, N.; Satomi, S. \& Inaba, H. (1998). A novel method of assessing carcinoma cell proliferation by biophoton emission. Cancer Lett Vol.127, No.1,(May 1998),pp.155-60, ISSN: 0304-3835

Tam, WY.; Chook, P.; Qiao, M.; Chan, LT.; Chan, TY.; Poon, YK.; Fung, KP.; Leung, PC. \& Woo, KS. (2009). The efficacy and tolerability of adjunctive alternative herbal medicine [Salvia miltiorrhiza and Pueraria lobata] on vascular function and structure in coronary patients. J Altern Complement Med Vol.15,No.4 (April 2009),pp.415-21, ISSN 1557-7708

Tashmukhamedova, MA.; Almatov, KT.; Syrov, VN.; Sultanov, MB. \& Abidov, AA. (1986). Comparative study of the effect of ecdysterone, turkesterone and nerobol on the function of rat liver mitochondria in experimental diabetes.VoprMed Khim Vol.32,No.5,(Sept-Oct 1986),pp.24-8, ISSN 0042-8809

Terasawa,K.(2004).Evidence-based reconstruction of Kampo medicine:part I -is Kampo CAM? Evid Based Complement Alternat Med Vol.1, No.1(Jun 2004),pp.11-6, ISSN $1741-4288$

Thadani,U. (2004).Current medical management of chronic stable angina. J Cardiovasc Pharmacol Ther Vol.9,Suppl.1 (Sept 2004),pp.S11-29, ISSN 1074-2484

Thadani,U. (2003).The pursuit of optimum outcomes in stable angina. Am J Cardiovasc Drugs Vol.3,Suppl.1, (2003),pp.S11-20

Thadani,U. (1999).Management of stable angina pectoris. Curr Opin Cardiol Vol.14,No.4(Jul 1999),pp.349-358, ISSN 0268-4705

Thyagarajan, A.; Zhu, J. \& Sliva, D.(2007). Combined effect of green tea and Ganoderma lucidum on invasive behavior of breast cancer cells. Int J Oncol Vol.30,No.4,(Apr 2007),pp.963-9, ISSN 1019-6439

Tilbary, RN. \& Quickenden, TI. (1988). Spectral and time dependence studies of the ultraweak bioluminescence emitted by the bacterium Escherichia coli. Photochem Photobiol Vol.47,No.1,(1988),pp.145-50, ISSN 0031-8655

Tin-Hay, E.; Poh, KK.; Lim, YT.; Fatt-Hoe, A.; Lee, CH.; Low, AF.; Lee, CH.; Teo, SG.; Lim, J.; Lim, IH. \& Tan, HC.(2009). Clinical predictors of stent thrombosis in the "real world" drug-eluting stent era. Int J Cardiol Vol.145,No.3,(Dec 2010),pp.422-25, ISSN 1874-1754 
Trautner, C. Haastert, B.; Spraul, M.; Giani, G.\& Berger, M.(2001). Unchanged incidence of lower-limb amputations in a German City, 1990-1998. Diabetes Care Vol.24,No.5,(May 2001),pp.855-9, ISSN 0149-5992

Tripathi,YB.; Singh, BK.; Pandey, RS. \& Kumar, M. (2005). BHUx: A Patent Polyherbal Formulation to Prevent Atherosclerosis. Evid Based Complement Alternat Med Vol.2,No.2,(Jun 2005),pp.217-221, ISSN 1741-4288

Trushin,M.(2003).Studies on distant regulation of bacterial growth and light emission. Microbiology Vol.149,Part2(Feb 2003),pp.363-8, ISSN 1350-0872

Vaisberg, AJ.; Milla, M.; Planas, MC.; Cordova, JL.; de Agusti, ER.; Ferreyra, R.; Mustiga, MC.; Carlin, L. \& Hammond, GB. (1989).Taspine is the cicatrizant principle in Sangre de Grado extracted from Croton lechleri. Planta Med Vol.55,No.2,(Apr 1989),pp.140-3, ISSN 0032-0943

Vandenbroek, I. Van Damme, P. \& Van Puyvelde,L.; Arrazola, S.\& De Kimpe, N. (2004). A comparison of traditional healer's medicinal plant knowledge in the Bolivian Andes and Amazon. Soc Sci Med Vol.59,No.4,(Aug 2004),pp.837-49, ISSN 02779536

Voeikov, VL. (2003).Mitogenic radiation, biophotons, and non-linear oxidative processes in aqueous media, In: Integrative Biophysics Biophotonics, FA. Popp, L. Beloussov, (Ed(s)), 331-359, Kluwer Academic Publishers, ISBN 978-140-2011-39-9, Dordrecht, The Netherlands

Volaco A, Chantelau E \& Richter, B. (2004). Outcome of critical foot ischaemia in longstanding diabetic patients: a retrospective cohort study in a specialised tertiary care centre. Vasa Vol. 33,No.1,(2004),pp.36-41. ISSN 0301-1526

von Stockar, U. \& Liu, J. (1999). Does microbial life always feed on negative entropy? Thermodynamic analysis of microbial growth. Biochim Biophys Acta Vol.1412,No.3,(Aug 1999),pp.191-211, ISSN 0006-3002

Vuksan, V.; Sievenpiper, JL.; Koo, VY.; Francis, T.; Beljan-Zdravkovic, U.; Xu, Z.\& Vidgen, E.(2000). American ginseng (Panax quinquefolius L) reduces post-prandial glycemia in nondiabetic subjects and subjects with type 2 diabetes mellitus. Arch Intern Med Vol.160,No.7,(Apr 200),pp.1009-13,ISSN 0003-9926

Wago, H. \& Deng, H. (2004).Chinese medicine and immunity, In: Complementary and Alternative Approaches to Biomedicine, E. L. Cooper, N. Yamaguchi, (Ed(s)), 167-79, KluwerAcademic/Plenum Publishers, ISBN 978-030-6482-88-5, New York,USA

Wang, BX.; Zhou, QL.; Yang, M.; Wang, Y.; Cui, ZW.; Liu, YQ. \& Ikejima, T. (2003). Hypoglycemic mechanism of ginseng glycopeptide. Acta Pharmacol Sin Vol.24, No.1 (2003), pp.61-6, ISSN 1745-7254

Wang, RT.; Shan, BE. \& Li, QX. (2002). Extracorporeal experimental study on immunomodulatory activity of Astragalus memhranaceus extracts. Zhongguo Zhong Xi Yi Jie He Za Zhi, Vol. 22, No. 6, (Jun 2002),pp. 453-6, ISSN 0254-6272

Wasser, SP. \& Weis, AL. (1999). Therapeutic effects of substances occurring in higher basidiomycetes mushrooms: a modern perspective. Crit Rev Immunol Vol.19 (1999), pp.65-96, ISSN 1040-8401

Wiener, N. (1954).The Human Use of Human Beings. Houghton-Miffin, ISBN: 0306803208, Boston 
Winell, K.; Niemi, M. \& Lepantalo, M. (2006). The national hospital discharge register data on lower limb amputations. Eur J Vasc Endovasc Surg Vol.32, No.1 (July 2006), pp.66-70, ISSN 1545-1550

World Health Organization. (2009) In: Cardiovascular disease: prevention and control. Available from

http://www.who.int/dietphysicalactivity/ publications/facts/cvd/en/. 2009

World Health Organization. 2011. In: WHO Fact sheet $N^{\circ} 312$. Availabe http://www.who.int/mediacentre/factsheets/fs312/en/

Wu, Y.; Wang, X. \& Li, M. (1998). Effect of Acanthopanacis senticosus on exercise performance under constant endurance load for elderly. Wei Sheng Yan Jiu No.27,(1998), pp.4214, ISSN 1000-8020

Yamada H. (2004). New scientific approach for natural medicines. In: Complementary and Alternative Approaches to Biomedicine, E.L. Cooper, N. Yamaguchi (Ed(s)), 27-33, Plenum Publishers, ISBN 978-030-6482-88-5, New York, USA

Yamaguchi, A.; Tanaka, M.; Naito, K.; Kimura, C.; Kobinata, T.; Okamura, H.; Ino, T. \& Adachi, H. (2009).The efficacy of intravenous milrinone in left ventricular restoration. Ann Thorac Cardiovasc Surg Vol.8,No.15(August 2009),pp.233-8. ISSN 1341-1098

Yang, M.; Wang, BX. \& Jin, YL. (1990). Effects of ginseng polysaccharides on reducing blood glucose and liver glycogen. Zhongguo Yao Li Xue Bao, No.11 (1990), pp.520-4, ISSN 0253-9756

Yang, T.; Jia, M.; Meng, J.; Wu, H. \& Mei, Q. (2006). Immunomodulatory activity of polysaccharide isolated from Angelica sinensis. Int J Biol Macromol Vol.39, No. 4-5, (Nov 2006), pp.179-84, ISSN 1478-9868

Yin, ZZ.; Zhang, LY. \& Xu, LN. (1980). The effect of dang-gui (Angelica sinensis) and its ingredient ferulic acid on rat platelet aggregation and release of 5-HT. Yao Xue Xue Bao Vol. 15, No.6, (Jun 1980) pp:321-6, ISSN 0513-4870

Young, HY.; Luo, YL.; Cheng, HY.; Hsieh, WC.; Liao, JC. \& Peng, WH. (2005). Analgesic and anti-inflammatory activities of [6]-gingerol. J Ethnopharmacol Vol.96,No.1-2,(Jan 2005), pp.207-10, ISSN 1872-7573

Zaragoza, F.; Iglesias, I. \& Benedi, J. (1985). Comparative study of the antiaggregation effects of anthocyanosides and other agents. Arch Farmacol Toxicol Vol.11,No.3,(Dec 1985), pp:183-8, ISSN 1578-5580

Zhang, HN. \& Lin, ZB. (2004). Hypoglycemic effect of Ganoderma lucidum polysaccharides. Acta Pharmacol Sin Vol.25,No.2, (Feb 2004) pp.191-5, ISSN 1745-7254

Zhang, L.; Wang, Y.; Wang, LZ. \& Gao, XM. (2004). Immunopotentiating effect of a 'Yang'promoting formula of traditional Chinese medicine on aged female BALB/c mice. Phytother Res Vol.18, No.10, (Nov 2004), pp.857-61, ISSN 0951-418X

Zhang, Y.; Mills, GL. \& Nair, G. (2002). Cyclooxygenase inhibitory and antioxidant compounds from the mycelia of the edible mushroom Grifola frondosa. J Agric Food Chem Vol.50,No.26,(Dec 2002),pp.7581-5, ISSN 1520-5118

Zhao, J.; Huang, X.; Tang, W.; Ren, P.; Xing, Z.; Tian, X.; Zhu, Z. \& Wang, Y. (2007). Effect of oriental herbal prescription Guan-Xin-Er-Hao on coronary flow in healthy volunteers and antiapoptosis on myocardial ischemia-reperfusion in rat models. Phytother Res Vol.21,No.10,(Oct 2007), pp. 926-31, ISSN 0951-418X 
Zhou, L.; Yang, Y.; Wang, X.; Liu, S.; Shang, W.; Yuan, G.; Li, F.; Tang, J.; Chen, M. \& Chen, J. (2007). Berberine stimulates glucose transport through a mechanism distinct from insulin. Metabolism Vol.56,No.3,(2007):405-12,ISSN 0026-0495

Zhu, XL.; Chen, AF. \& Lin, ZB. (2007). Ganoderma lucidum polysaccharides enhance the function of immunological effector cells in immunosuppressed mice. $J$ Ethnopharmacol Vol.111, No.2, (May 2007), pp.219-26, ISSN 0378-8741 


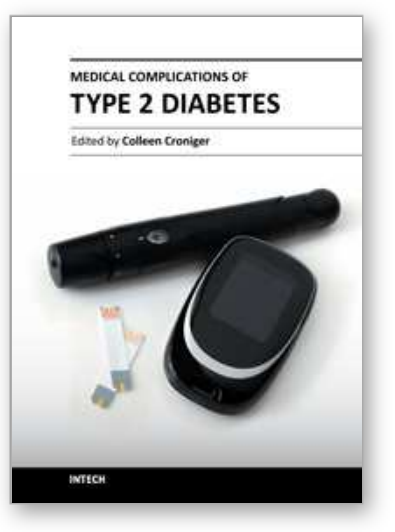

\author{
Medical Complications of Type 2 Diabetes \\ Edited by Dr. Colleen Croniger
}

ISBN 978-953-307-363-7

Hard cover, 412 pages

Publisher InTech

Published online 12, September, 2011

Published in print edition September, 2011

Obesity and type 2 diabetes are increasing worldwide problems. In this book we reviewed insulin secretion in both healthy individuals and in patients with type 2 diabetes. Because of the risk associated with progression from insulin resistance to diabetes and cardiovascular complications increases along a continuum, we included several chapters on the damage of endothelial cells in type 2 diabetes and genetic influences on endothelial cell dysfunction. Cardiovascular complications occur at a much lower glucose levels, thus a review on the oral glucose tolerance test compared to other methods was included. The medical conditions associated with type 2 diabetes such as pancreatic cancer, sarcopenia and sleep disordered breathing with diabetes were also discussed. The book concludes with several chapters on the treatments for this disease offering us hope in prevention and successful alleviation of the co-morbidities associated with obesity and type 2 diabetes.

\title{
How to reference
}

In order to correctly reference this scholarly work, feel free to copy and paste the following:

J. Olalde, A. Antoshechkin, O. del Castillo, R. Guzmán and F. Améndola (2011). Design and Evaluation of a Complex Phytoceutical Formulation for Circulatory Diseases, Medical Complications of Type 2 Diabetes, Dr. Colleen Croniger (Ed.), ISBN: 978-953-307-363-7, InTech, Available from: http://www.intechopen.com/books/medical-complications-of-type-2-diabetes/design-and-evaluation-of-acomplex-phytoceutical-formulation-for-circulatory-diseases

\section{INTECH}

open science | open minds

\section{InTech Europe}

University Campus STeP Ri

Slavka Krautzeka 83/A

51000 Rijeka, Croatia

Phone: +385 (51) 770447

Fax: +385 (51) 686166

www.intechopen.com

\section{InTech China}

Unit 405, Office Block, Hotel Equatorial Shanghai

No.65, Yan An Road (West), Shanghai, 200040, China 中国上海市延安西路65号上海国际贵都大饭店办公楼 405 单元

Phone: +86-21-62489820

Fax: $+86-21-62489821$ 
(C) 2011 The Author(s). Licensee IntechOpen. This chapter is distributed under the terms of the Creative Commons Attribution-NonCommercialShareAlike-3.0 License, which permits use, distribution and reproduction for non-commercial purposes, provided the original is properly cited and derivative works building on this content are distributed under the same license. 